Structure, geometry and formation of brittle discontinuities in

anisotropic crystalline rocks of the Central Gotthard Massif, Switzerland

\author{
Journal Article \\ Author(s): \\ Zangerl, Christian; Loew, Simon; Eberhardt, Erik \\ Publication date: \\ 2006-11 \\ Permanent link: \\ https://doi.org/10.3929/ethz-b-000024043
}

Rights / license:

$\underline{\text { In Copyright - Non-Commercial Use Permitted }}$

Originally published in:

Eclogae Geologicae Helvetiae 99(2), https://doi.org/10.1007/s00015-006-1190-0 


\title{
Structure, geometry and formation of brittle discontinuities in anisotropic crystalline rocks of the Central Gotthard Massif, Switzerland
}

\author{
Christian Zangerl ${ }^{1,2}$, SimOn LOEW $^{1}$ \& EriK EberhardT ${ }^{1,3}$
}

Key words: Brittle fault zones, joint pattern, Gotthard Massif, granite

\begin{abstract}
Spatial occurrence, structural architecture and formation of brittle fault zones and joints are investigated by outcrop observations, scanline mapping, and light- and scanning electron microscopy in an anisotropic crystalline rock mass (e.g. granites, para-gneisses and schists) of the central Gotthard massif in the Swiss Alps. The analysis presented illustrates that several pre-fault anisotropic features (i.e. dykes, ductile shear zones, foliation and presumably a pre-existing meso-scale fracture set) control the nucleation and propagation of brittle faults. Three sets of brittle fault zones striking NE-SW, NNE-SSW and WNWESE can be distinguished. They formed through cataclasis at temperatures below $300{ }^{\circ} \mathrm{C}$, and were activated predominately in a strike-slip regime. Up to five joint sets were mapped and characterized according to orientation, frequency, spacing and formation. Finally a regional fan structure was established in the Gotthard Pass area, encompassing the main foliation, steeply dipping joints and brittle fault zones, each of which shows the same orientation and location of the symmetry plane (NE-SW orientated).
\end{abstract}

\section{ZUSAMMENFASSUNG}

Der vorliegende Artikel präsentiert Untersuchungen über den Aufbau, die räumliche Verteilung und die Entstehung von spröden Störungszonen und Kluftstrukturen in anistropen Gesteinen des zentralen Gotthardmassivs der Schweizer Alpen. Dabei wurde auch der Einfluss unterschiedlichster bereits existierender Strukturen, wie z.B. Intrusionsgänge, duktile Scherzonen, Schieferungsflächen oder Klüfte auf die Entstehung und Ausbildung von jungalpinen spröden Störungszonen im Detail untersucht. Die Ergebnisse basieren auf Aufschlussbeobachtungen, "Scanline-Aufnahmen" und Licht- bzw Elektronenmikroskopischen Untersuchungen. Drei Störungssysteme, ein NESW streichendes Hauptsystem, ein NNE-SSW und ein WNW-ESE streichendes System, welche vorwiegend als Blattverschiebungen fungieren, wurden kartiert. Entsprechend den lithologischen Einheiten konnten bis zu 5 verschiedene Kluftfamilien unterschieden und im Hinblick auf deren geometrische Parameter und Entstehung analysiert werden. Die im zentralen Gotthardmassiv bekannte Fächerstruktur der Hauptfoliation wird auch durch ein Kluftsystem und spröde Störungszonen mit gemeinsamer NE-SW streichender Symmetrieebene abgebildet.

\section{Introduction}

The external crystalline massifs of the central Swiss Alps (Aar and Gotthard massifs) have been studied intensively during the past 15 years, mainly to support the construction of the Lötschberg and Gotthard Base Tunnels, currently underway. The major geological obstacles faced by these tunnels are related to faults and shear zones intersected in the crystalline basement rocks (face instability, strongly squeezing ground, overbreaks, water inflows). In addition to these construction hazards, surface settlements induced by draining fault zones are of concern, especially in areas where the tunnels run close to existing hydroelectric dams. In the Gotthard Pass area, the spatial relationship between large water inflow rates into the Gotthard A2 highway tunnel (built in the 1970's), flowing from two distinct brittle fault zones intersecting the tunnel, and the maximum surface subsidence measured along the Gotthard pass road, above and adjacent to the tunnel, can be directly correlated (Zangerl et al. 2003). A hypothesis was thus developed that these brittle fault zones may act as highly permeable conduits, which can undergo large normal- and shear displacements through rock mass consolidation processes as the stress

\footnotetext{
${ }^{1}$ Engineering Geology, Swiss Federal Institute of Technology ETH, Zürich, Switzerland

2 alpS - Centre for Natural Hazard Management, Grabenweg 3, A-6020 Innsbruck, Austria

${ }^{3}$ Geological Engineering, University of British Columbia, V6T 1 Z4 Vancouver, BC, Canada

Corresponding Author: Christian Zangerl, alpS - Centre for Natural Hazard Management, Grabenweg 3, A-6020 Innsbruck, Austria

E-mail address: zangerl@alps-gmbh.com
} 
state changes due to pore pressure drawdown. Similarly, the spatial configuration and geometrical properties of smaller meso-scale fractures were also perceived as having a controlling influence on the mechanical and hydrogeological behaviour of the rock mass. To investigate the means by which the hazard potential arising from tunnel-induced surface subsidence may be assessed and to better understand the underlying mechanisms, coupled hydro-mechanical numerical simulations were required, for which data pertaining to the orientation and spacing of the brittle faults and the surrounding fractured matrix are essential.

Of similar importance is the tectonic history that promoted the formation of the faults and meso-scale discontinuities, as this too has been shown to have an impact on the hydraulical and mechanical properties of the structures. Esaki et al. (1999) demonstrated that fracture aperture and stiffness can vary as a function of shear displacement, whereas Sausse et al. (2001) showed the same with respect to fault healing and alteration/ dissolution processes. Brittle faults may also involve slip parallel to a single discrete fracture plane, but fault "zones" are formed through subparallel or anastomosing interconnected closely-spaced faults. Laboratory compression tests suggest that faults rarely originate as shear fractures in isotropic rock masses (Petit \& Barquins 1988) and that pre-existing dilatant fractures and rock anisotropy would strongly influence fault growth. In laboratory compression tests on anisotropic rocks (i.e. schists or gneisses), rock strength significantly decreases when applying axial loads inclined $30^{\circ}$ to $60^{\circ}$ to the foliation (Gottschalk et al. 1990; Brosch et al. 2000).

To understand faulting processes several scale-dependent mechanisms have been proposed. For example, a large-scale planar fault is likely to have developed through the coalescence of propagating micro-cracks, joints and/or veins. Field observations (Hancock 1985; Willemse et al. 1997; Mollema \& Antonellini 1999) and laboratory experiments (Scholz 1968) confirm this hypothesis. Similarly, larger fault zones have been observed as forming through the propagation and coalesence of smaller fault segments (e.g. Peacock 1991; Peacock \& Sanderson 1991; Cartwright et al. 1995; Willemse 1997). Most of these faulting mechanisms were based on observations in sedimentary rocks. Another type of faulting mechanism, based on observations in crystalline rock, is related to shear traction on a meso-scale planar discontinuity that generates fracture parallel slip (Segall \& Pollard 1983; Granier 1985; Martel et al. 1988; Martel 1990; Cruikshank et al. 1991; Martel \& Boger 1998; Peacock 2001; Wilkins et al. 2001). In other words, preexisting discontinuities formed in tension (mode I), but were followed by in-plane shear (mode II) to create faults. Increasing movement along the plane generally results in fracturing and breaking off of wall rock fragments, during the process of cataclasis.

Martel \& Peterson (1991) described lamprophyre dykes and ductile shear zones in granitic host rocks that act as a nucleus for brittle faulting. Furthermore, pre-existing shear zones (i.e. mylonitic rocks) or foliation structures favour the faulting process sub-parallel to these structures. The coexistence of cataclastic and mylonitic fabrics within a single fault zone is frequently described in the literature and attributed to a progressive phase of deformation within a single phase of faulting (Sibson 1977; Simpson 1986), or to different tectonic events acting along relic fabrics within a reactivated fault zone (Gaudemer \& Tapponnier 1987; Tremblay \& Malo 1991).

Geometric and mechanical characterization of rock joints and brittle fault zones provides the basis for most of the work of engineering geologists and geotechnical engineers when dealing with rock masses. Moreover, characterization of rock joints plays an important role in investigations of joint genesis (Dershowitz \& Einstein 1988). Often, in many geological or geotechnical studies, only dip and dip direction are measured. Detailed data about individual joint features i.e. trace length/size, aperture, surface roughness and morphology that influence the mechanical behaviour of the fracture network are less frequently available. Additionally, parameters characterizing the joint network, i.e. degree of interconnection, termination style, spatial heterogeneity, anisotropy, fracture frequency, spacing, etc., are important to adequately describe the rock mass (La Pointe 1993). Presumably the most important parameters, the joint spacing measured through scanline mapping techniques along rock cuts or boreholes provide a measure of the "quality" of the rock mass. Also, the structural anisotropy of a fractured rock mass can only be deduced from both the orientation and spacing properties of individual fracture sets (Rouleau \& Gale 1985). Apart from fundamental engineering needs, spacing distributions of joint sets also provide useful insight into the fracturing process (Rives et al. 1992; Boadu \& Long 1994).

Accordingly, discontinuity data (i.e. brittle fault zones and joints), as presented in this paper, were analysed with regard to spatial geometrical and structural properties, but also to mechanical formation processes, so as to provide the basis for subsequent numerical models related to the potential subsidence hazard problem in the central Gotthard massif. Analysis and interpretation of this data with regard to regional tectonic models was not an objective of the study.

\section{Regional geological setting}

The Gotthard massif is situated in the central Swiss Alps (Fig. 1) and covers an area of $580 \mathrm{~km}^{2}$. It outcrops in the form of an $80 \mathrm{~km}$ long and $12 \mathrm{~km}$ wide NE-SW striking mountain range. The study area is located in the central part of the massif through which the Gotthard rail tunnel (SBB-Tunnel) and highway tunnel (A2-Tunnel) are driven (Fig 1). The Gotthard massif consists of a pre-Variscan, poly-orogenic and polymetamorphic basement (primarily gneisses, schists, migmatites and amphibolites), which are intruded by Variscan magmatic rocks (Labhart 1999) (Fig. 1 and 2). The Variscan intrusives in the Gotthard pass region are mostly granitoids and were intruded during two different phases separated by several million years. During the older phase (303-301 Ma) the Fibbia- 

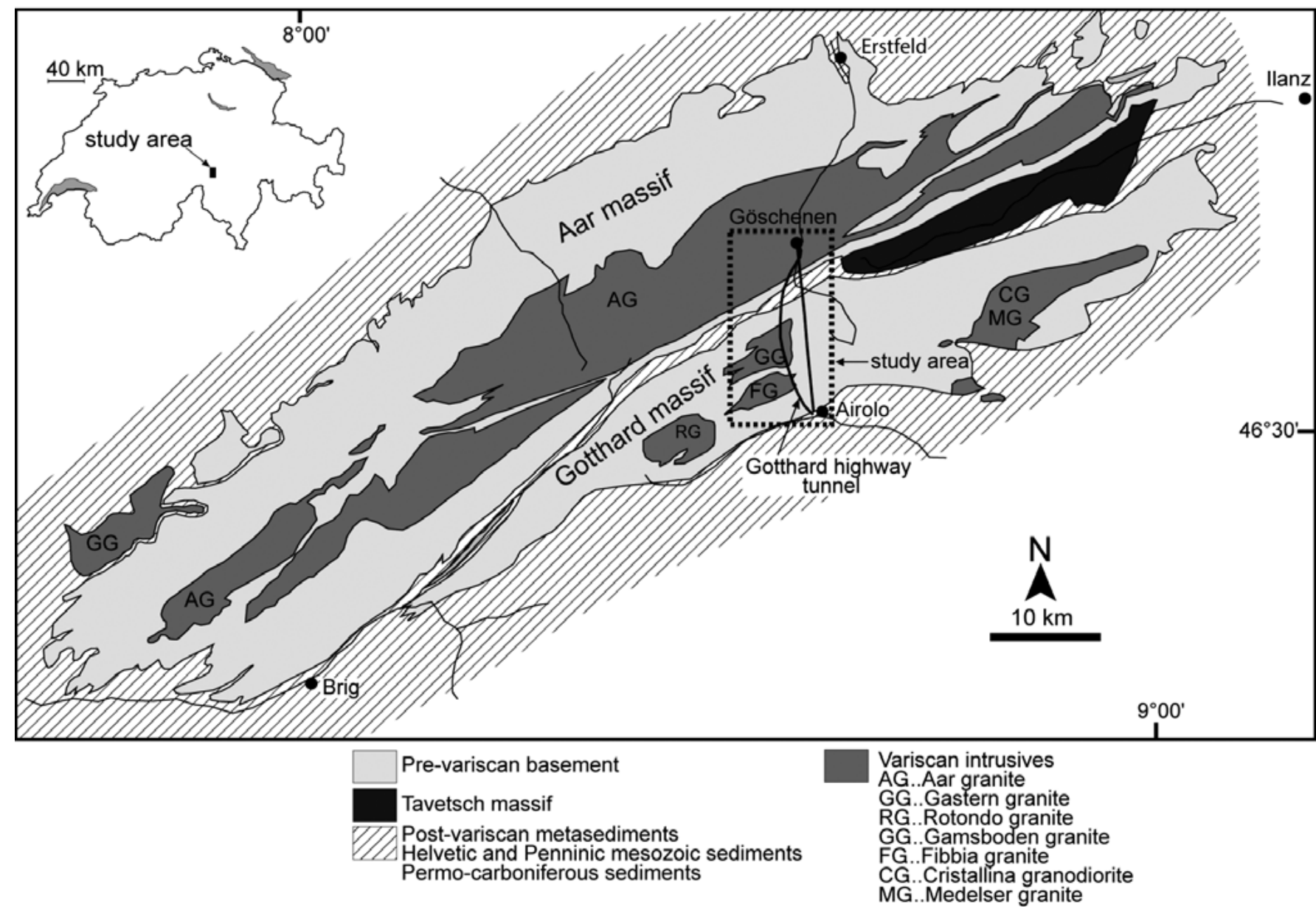

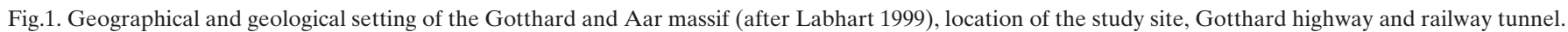

and Gamsboden-granites were intruded as shown in figure 2. The younger intrusion phase took place between 295-293 Ma and involved the crystallization of the Rotondo, Mt. Prosa and Winterhorn-aplite granites (Oberli et al. 1981; Sergeev \& Steiger 1995). The Fibbia-granite, located in the southern part of the study area, is constrained along its southern margin by a 100 to $300 \mathrm{~m}$ thick layer of Rotondo-granite and eastwards by the Mt. Prosa granite. Going north to the northern boundary of the Gamsboden-granite, a several hundred metres thick layer of Winterhorn-aplite granite separates the Gamsbodengranite from the pre-Variscan basement rocks. The northern boundary of the Gotthard massif is marked by an Alpine-tectonic contact to the Permo-Carboniferous and Mesozoic sediments (Urseren-Gavera-zone; Wyss 1986) and the Tavetsch massif along the Rhine-Rhone valley. This heavily tectonized zone separates the Gotthard- from the Aar-massif. At the southern border of the Gotthard massif another steeply dipping zone of parautochtonous Mesozoic metasediments separates this massif from the units of the Pennine domain. This zone consists of tectonic units referred to as "Piora zone" east and "Nufenen zone" west of the Gotthard pass, respectively. They are characterised by schists and a sequence of carbonates, gypsum/anhydrite of Triassic to Jurassic age (Herwegh \& Pfiffner 1999).

During Alpine metamorphism, greenschist facies conditions were reached throughout the Gotthard massif, with an increase in peak pressure and temperature from north to south. Along the southern boundary, amphibolite facies conditions were achieved (Frey et al. 1980; Labhart 1999). The main phase of Alpine deformation in the Gotthard massif occurs near the Eocene-Oligocene boundary around 35 to $30 \mathrm{Ma}$ (Schmid et al. 1996), corresponding with a peak metamorphic overprint characterised by a ductile deformation regime. In the central Gotthard massif Alpine shear zones and foliation strike NE-SW or E-W and dip southwards in the northern part but northwards in the southern part, forming a fan-like structure (Labhart 1999). According to Steck (1968), Merz (1989), Marquer (1990) and Pettke \& Klaper (1992) the formation of the ductile deformation structures (i.e. foliation and shear zones) predominately occurred in a NW-SE orientated compressional 


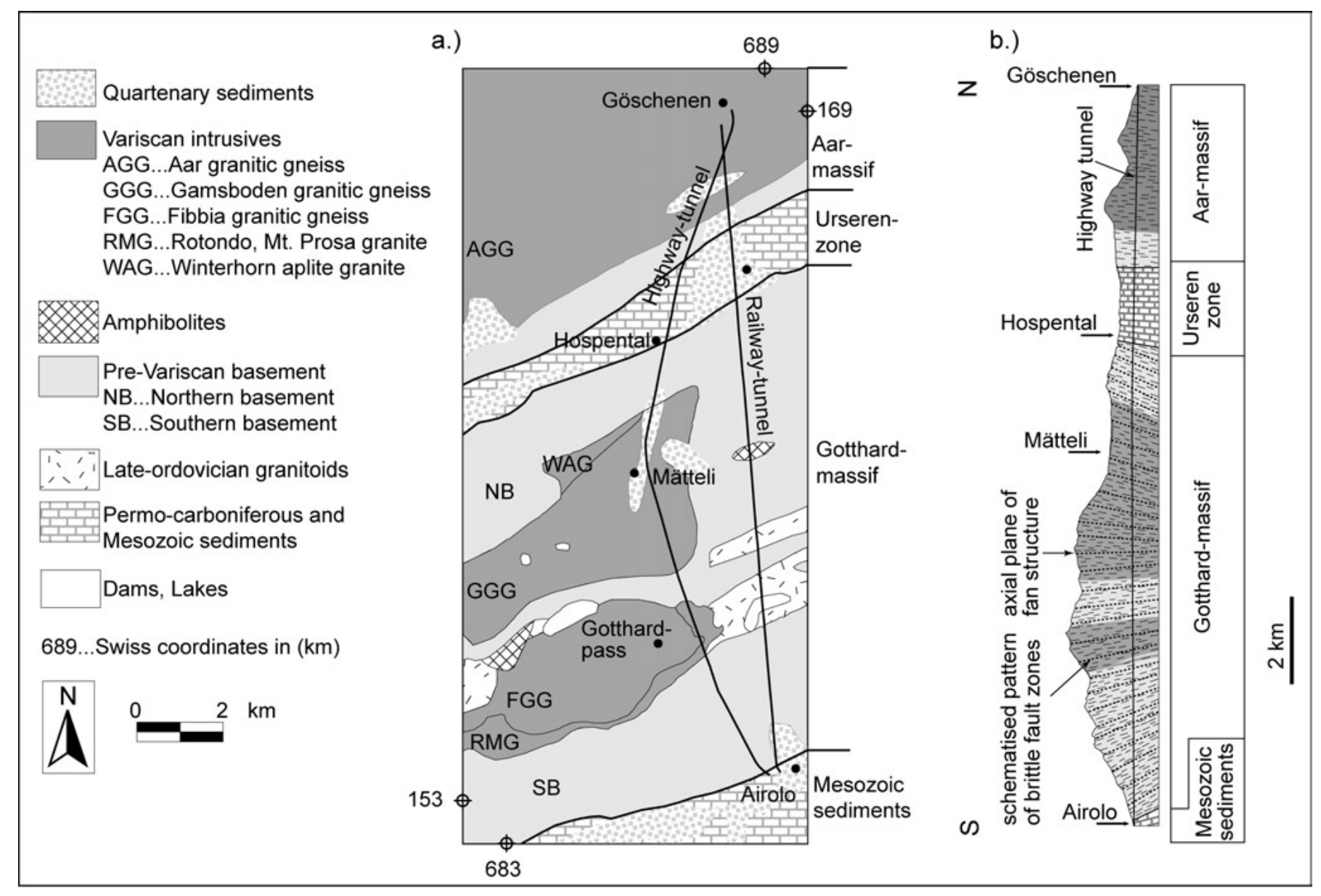

Fig. 2. a) Geological overview of the study area. b) Cross section along the Gotthard highway tunnel showing geological and tectonic units (modified after Keller et al. 1987). Within the Gotthard massif a schematised pattern of foliation and brittle fault zones (i.e. the fan structure) is shown.

stress regime. A higher degree of ductile overprint, represented by penetrative foliation textures and shear zones is clearly observed in the Fibbia- and Gamsboden-granite. The younger intrusives, the Winterhorn-, Rotondo-granites etc., also show ductile structures but these are much more limited to shear zones. As such, Guerrot \& Steiger (1991) postulate a Variscan deformation phase between the older and younger intrusion events. Conversely, Marquer (1990) argues that deformation in the region is only Alpine (i.e. significantly younger), although it should be noted that his study primarily focussed on the Fibbia-granite. Addionally, Merz (1989) attributed the foliation of the Medel granite exclusively to the Alpine deformation phase.

Ongoing deformation gradually changed from a ductile to a brittle deformation regime characterised by brittle faulting. Little work has been done on the formation of brittle structures within the Gotthard massif (Kvale 1966; Arnold 1970; Luetzenkirchen 2002), even though they are of major importance to understanding the tectonic evolution of the region. As shown by Luetzenkirchen (2002) brittle faulting in the eastern
Gotthard massif occurred along a retrograde metamorphic path and mainly along pre-existing ductile shear zones. Brittle fault zones are characterized by, probably dextral, strike-slip faulting. Mineralogical observations reported by Luetzenkirchen (2002) suggest that the brittle deformation occurred within a temperature interval of $190^{\circ} \mathrm{C}$ and $300^{\circ} \mathrm{C}$. The deformation activity in the time span between a time marked by this lower temperature boundary and today is considered very low, i.e. neotectonic activity in the eastern Gotthard massif should be negligible.

Eckhardt et al. (1983) and Persaud \& Pfiffner (2004) interpreted several fault scarps mapped within the eastern Aar massif, trending ENE or less frequently E-W, as being postpostglacial tectonic faults. However, as shown by Laws (2001), the fault rocks in the eastern Aar massif are primarily composed of ductile mylonites and phyllonites, and fractures oriented parallel and oblique to the foliation are often filled with greenschist facies, metamorphic infillings and micro-breccia. Therefore these fault scarps might have been generated by post-glacial unloading and gravitational slope movements. 
Recent stress data derived from fault plane solutions of seismic events occurring in the region surrounding the Gotthard massif indicate a strike-slip or extensional regime (Maurer et al. 1997; Deichmann et al. 2000). In other neighbouring regions, Kastrup (2002) found that strike-slip to thrust faulting conditions dominate. It should be noted though, that since these cited studies refer to surrounding regions, a direct comparison to the central Gotthard massif may not be applicable.

\section{Brittle discontinuities}

Brittle discontinuities discussed within this study were classified into faults or joints. According to Angelier (1994), faults are discontinuities for which visible displacements have occurred, primarily parallel to the fault plane. Brittle fault rocks result from the process of cataclasis and are classified according to Ramsay \& Huber (1987). Whereas the terms "fault breccia" and "gouge" apply to initially cohesionless fault rock, the term "cataclasite" is used for fault rock that possesses a primary internal cohesion. Although both breccia and gouge are cohesionless materials, they may become impregnated and sealed by crystal growth in the voids to produce cemented breccia or cemented gouge. Hancock (1985) defined a joint as a fracture in meso-scale dimension for which no shear offset or dilation is detectable in the field. Conclusively, we apply "joints" as a field term to meso-scale fractures that either show tensile opening, tensile surface features (e.g. plumes), or do not have any evidence for shear/normal displacements. The term meso-scale is used to embrace fractures that range in size from centimetres to several 10's of metres, and that are usually observable in a single continuous exposure (Hancock 1985).

Meso-scale joints were mapped on individual surface outcrops sampled across the study region (in total about 1900 joints larger than 1-m trace length) and by applying scanline joint mapping techniques to rock faces along or near the Gotthard pass road (in total about 2100 joints larger than $0.3 \mathrm{~m}$ ). The scanline mapping technique is described in more detail in Priest (1993) and involves a relatively simple, reproducible and systematic method for discontinuity mapping on larger exposed rock faces (e.g. quarry or road cuts). The method enables orientation data, joint frequency, spacing, trace length and fracture termination estimates to be made and statistically treated. Several scanlines, each between 13 and $79 \mathrm{~m}$ in length, were mapped, achieving a total length of $800 \mathrm{~m}$ of sampled data. Of this, $384 \mathrm{~m}$ pertains to the mapping of the Gamsboden granitic gneiss where the joint normal set spacing and frequency were analysed for this paper. Most of the scanlines used were aligned sub-horizontal in a N-S direction and therefore crosscut the main geological structures. Care was taken to distinguish between natural and blast induced joints where scanlines were performed along road cuts.

An extensive surface mapping campaign focussing on brittle fault zones was also carried out and supplemented with data collected at depth from the A2-Gotthard safety tunnel, which runs parallel to the highway tunnel (Schneider 1979; Wanner
1982). Fault zone measurements undertaken in the Gotthard safety tunnel provide one-dimensional line data of fault orientation, frequency and spacing similar to those that are obtained by scanline mapping techniques for meso-scale joint on surface. In addition lineaments and faults were mapped on black and white aerial photos and verified in the field.

\section{Spatial occurrence and geometry of brittle fault zones}

\subsection{Spatial occurrence and fault orientation}

Figure 3 shows the trace pattern of mapped and inferred brittle fault zones on the surface, and the strike and dip direction of faults measured along the Gotthard highway-safety tunnel between Hospental and Airolo. Two major sets striking NE-SW (set BF1) and NNE-SSW (set BF2), and one minor WNWESE set (set BF3) can be distinguished. Brittle fault zone orientations based on surface and tunnel mapping are plotted in figure 4a,b using equal-area Kamb-contour pole plots projected on the lower-hemisphere. In these figures, it can be seen that data from both the tunnel and surface show similar pole distribution patterns, although it is not possible to clearly resolve the three different fault sets. The Angelier-diagram in figure $4 \mathrm{c}$ includes only surface fault planes in which striations and in some cases shear sense could be mapped, and through which the inferred sets are more distinctly discerned. The mean strike of the NE-SW (BF1) and NNE-SSW (BF2) orientated fault sets intersect each other at a relatively low angle of approximately $30^{\circ}$ (Figs. 3 and 5). In general, the location where both sets intersect each other is covered with debris and therefore clear observations regarding the manner of intersection cannot be discerned. Nevertheless it could be observed how the two brittle fault sets intersect each other at an angle of $25^{\circ}$ to form a conjugate fault system. WNW-ESE striking fault zones are statistically minor but can be clearly seen in aerial photos of the Fibbia-granitic-gneiss (Fig. 5) and through field mapping observations. Figure 5 also shows that the major NESW striking fault zones splay into different branches within a tight $20^{\circ}$ arc. The NNE-SSW striking faults terminate at the major NE-SW structures. The pitch of slickenside striations on fault planes is mostly gently plunging, $83 \%$ of all measured plunges varying between 0 and $35^{\circ}$ (Fig. 4c). The remaining $17 \%$ striations plunge steeply, ranging from 37 to $88^{\circ}$. All striations were observed and measured on smooth, polished, mirror-like slickenside planes representing the contact shear plane or along the contact between the fault gouge layer with the intact host rock. Based on these observations, most of the mapped fault zones can be classified as pure strike-slip faults following the classification scheme by Angelier (1994). The rest can be grouped as oblique-slip faults. All of these observations relate to the youngest brittle faulting events.

Shear movement indicators (i.e. slickensides, offset markers, Riedel shears) from NE-SW and NNE-SSW striking fault zones frequently show a right-lateral sense of slip. Left-handed strike slip faults, sometimes in relation with conjugate fault 


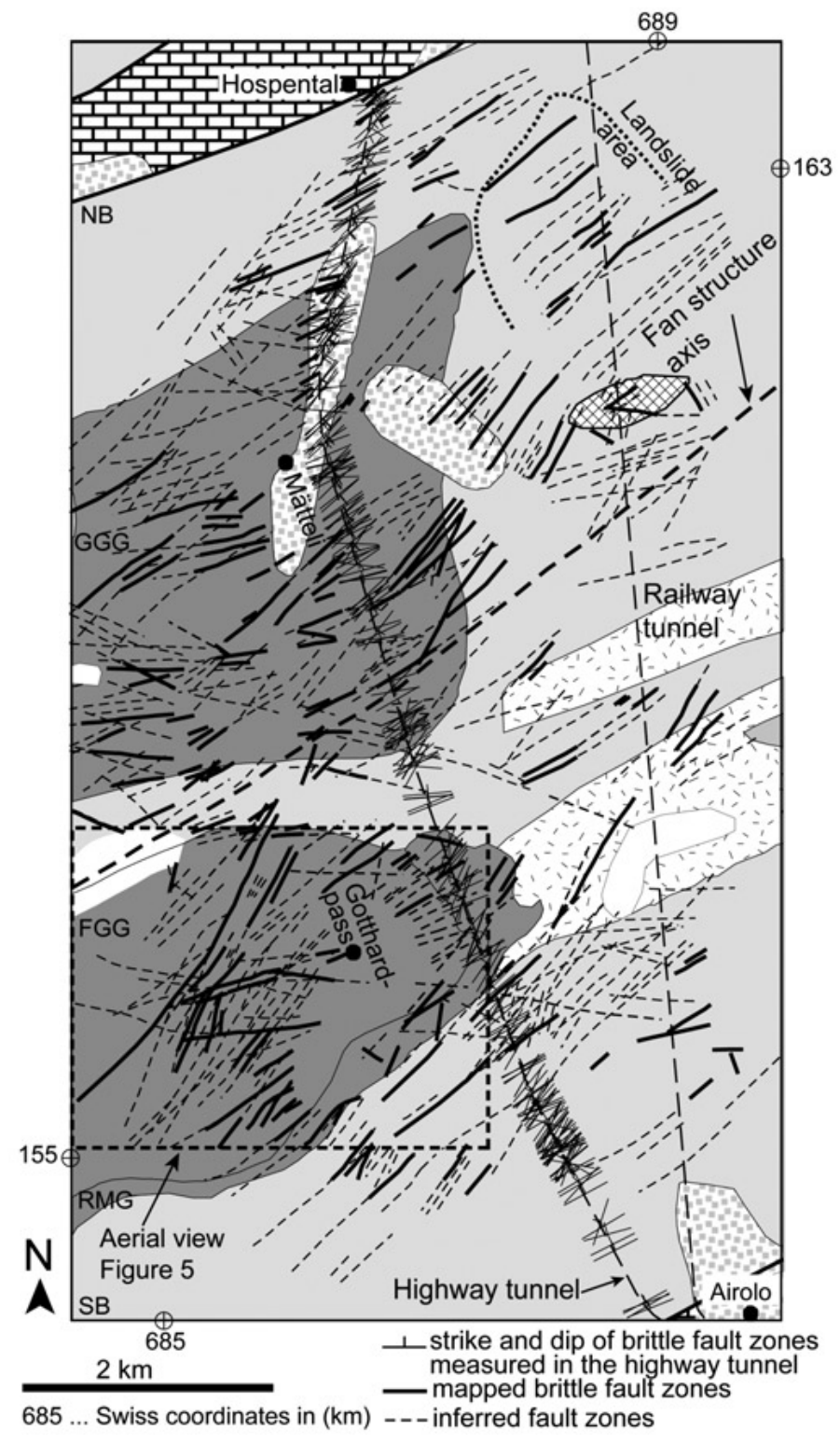

Fig. 3. Fault zones mapped in the area of the Gotthard pass. Black lines represent mapped brittle fault zones, dashed lines represent inferred fault zones based on aerial photos and geomorphological mapping. Strike and dip of mapped brittle fault zone within the Gotthard safety tunnel. See Fig. 2 for legend.

systems, were also observed but are less common (Fig. 4c). Offset values ranging from a few $\mathrm{cm}$ to a maximum of $50 \mathrm{~m}$ were mapped through the help of displacement markers, most notably NW-SE striking lamprophyric dykes. Large-scale offset values, i.e. greater than $100 \mathrm{~m}$, are not present, as can be demonstrated by discordant lithological boundaries (relative to the orientation of brittle fault zones) for which no noticeable displacements occur. Such displacements would be expected across Alpine fault zones activated in a strike-slip regime which in turn would dislocate intrusion contacts of the
Gamsboden- and the Fibbia-granitic-gneiss (Fig. 3). Only east of Mätteli does a clearly buckled intrusion contact allow for an interpretation of right-handed strike-slip displacements on the order of magnitude of several $100 \mathrm{~m}$. Given the convoluted nature of these intrusion contacts, however, it is not possible to decide if this structure is primary or fault-related.

Due to the lack of fully exposed outcrops, the determination of the shear sense for WNW-ESE striking fault zones (set BF3) becomes more complicated. Limited data from slickensides and offset markers show both left- and right-handed shear senses. Arnold (1970) observed left-handed shear for E-W striking brittle fault zones $12 \mathrm{~km}$ east of the Gotthard pass in the preVariscan basement unit. Shear sense indicators further suggest that these faults could have developed through conjugate faulting processes together with the NE-SW striking fault sets.

Brittle faults zones in the central Gotthard massif form a fan-like structure characterised in the northern part by southeast dipping faults and in the southern part by northwest dipping faults. A N-S profile along the Gotthard highway tunnel illustrates the fan structure of faults and shows the point of dip reversal (Swiss coordinates: $\mathrm{X}=686840 \mathrm{~m}, \mathrm{Y}=158765 \mathrm{~m}$; Fig. 6). The geological cross section along the Gotthard highway tunnel shown in figure $2 \mathrm{~b}$ schematically clarifies the nature of the fan structure (modified after Keller et al. 1987). The orientation of the sub-vertically dipping "axial plane" of the fan structure drawn on figure 3 is based on surface and tunnel measurements and strikes $60^{\circ}$ from NE to SW.

\subsection{Spacing and frequency of brittle fault zones}

The total spacing histogram derived from all brittle fault zones intersecting the Gotthard safety tunnel within the rock units of the Gotthard massif is shown in figure 4e. The total spacing is defined as the spacing between a pair of immediately adjacent discontinuities, measured along a line of general, but specified, location and orientation (Priest 1993). A total mean spacing of about $35 \mathrm{~m}$ was found, which results in a linear frequency of 0.029 along the tunnel axis (Zangerl et al. 2003). The data set shows a reasonable fit for the negative exponential- and Weibull-probability density distributions, with the Weibulldistribution providing the better fit of the two. The width of the fault zone cores measured within the Gotthard safety tunnel by Schneider (1979) and Wanner (1982) ranges between several millimetres and 2 meters, whereby a mean of $0.22 \mathrm{~m}$ was observed. Of course, a high lateral fault width variability has to be considered for this data base.

\section{Brittle fault zone architecture}

Igneous dykes, ductile shear zones and eventually early joints were seen to form different types of pre-faulting anisotropy and heterogeneity, which control the formation of brittle fault zones and their internal architecture. Following a relative chronological order, dykes are the oldest (mainly Variscan) anisotropy, ductile structures are at an intermediate age (mainly 


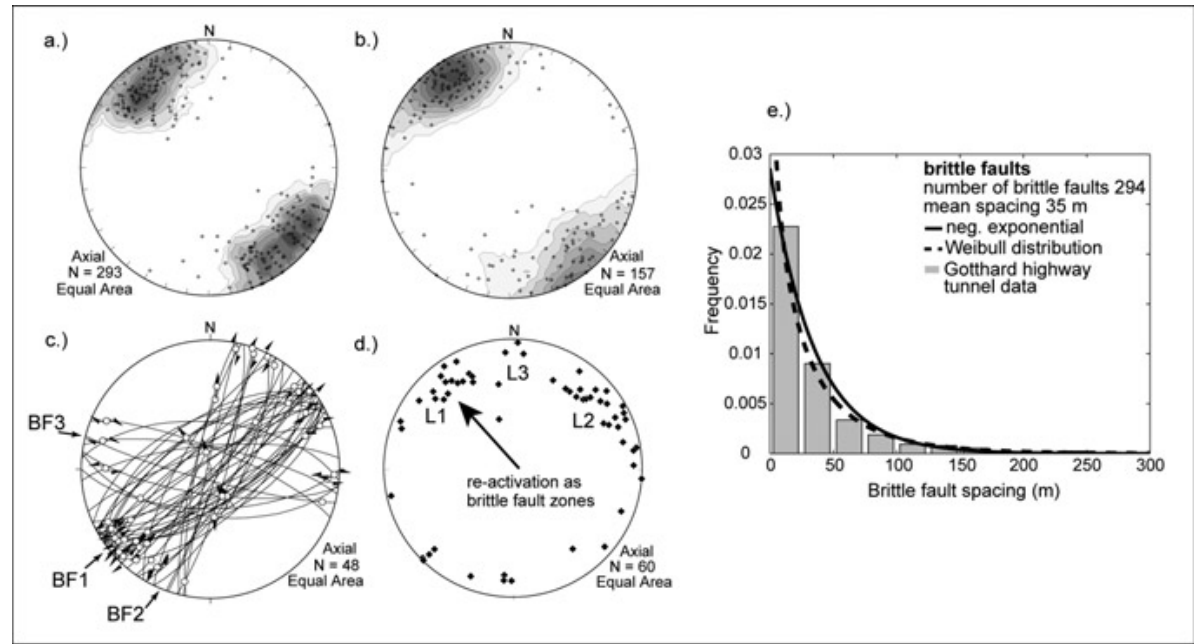

Fig. 4. a) Brittle fault zones mapped within the Gotthard safety tunnel. b) Brittle fault zones mapped on surface (plotted as poles). c) Brittle fault zones mapped on surface with measured slickenside striations and shear sense indicators. d) Orientation of intrusion contacts for the lamprophyric dykes (plotted as poles). e) Total spacing histogram of brittle fault zone measured within the Gotthard highway safety tunnel.

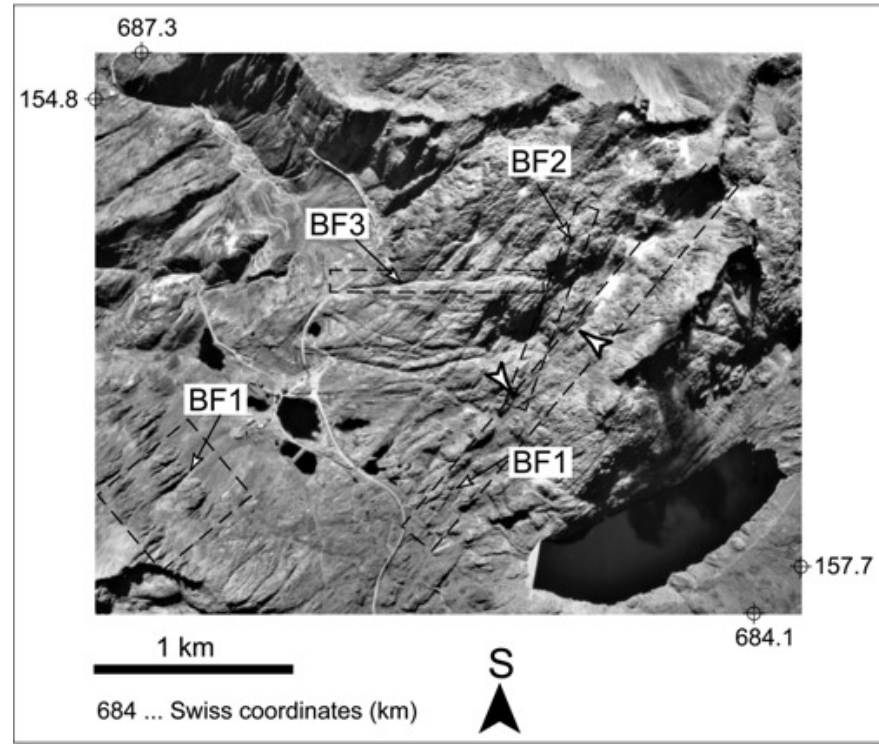

Fig. 5. Aerial view of a heavily faulted region in the Fibbia granitc gneiss showing the individual fault sets (i.e. BF1, BF2 and BF3) marked by dashed black frames. Reproduziert mit Bewilligung von swisstopo (BA 068054)

Meso-Alpine), and joints are the youngest source (mainly Late-Alpine); see Fig. 7. Superposition of these anisotropic features was frequently observed. For example, geological boundaries (e.g. dykes) may deform under ductile regimes (e.g. shear zones) and sub-sequentially act as nuclei for brittle fault zone propagation. The corresponding fault zone architectures are described in the following paragraphs.

\subsection{Brittle fault zones controlled by igneous dykes and compositional layering}

Within the granitic gneisses, the frequent occurrence of brittle fault zones at contacts to Variscan igneous dykes indicated

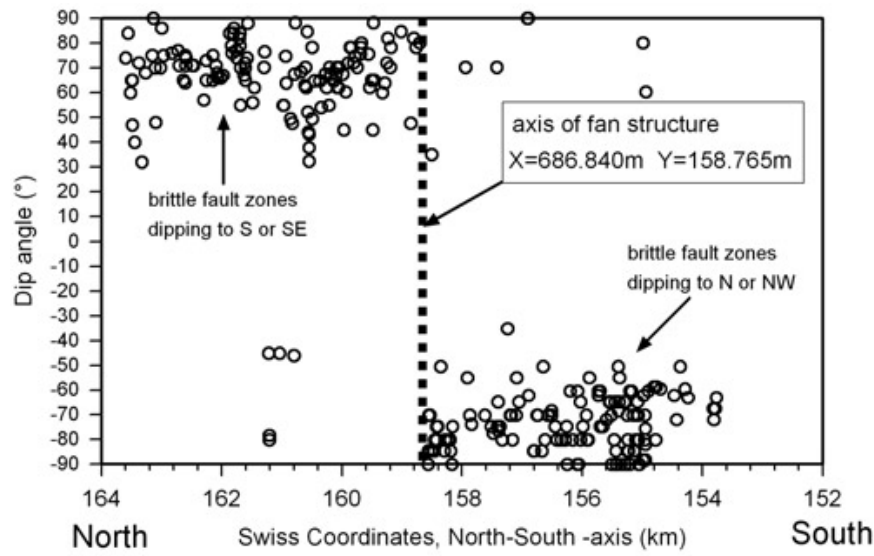

Fig. 6. North-South profile along the Gotthard highway tunnel showing the dip angle of the brittle fault zones and the location of the fan structure axis.

their susceptibility to serve as nuclei for fault zones. The geochemistry of these dykes within the Gotthard region was intensively studied by Oberhänsli (1985). They were classified as lampropyhres, kersantites and spesserartites. Within the study area numerous dykes were mapped with widths varying from several centimetres to several metres. Orientation measurements of intrusion contacts to the granitic host rock show two main sets, one striking NE-SW (set L1), the other striking NWSE (set L2; Fig. 4d). A minor set can also be discerned with contacts that strike E-W (set L3). Occasionally, the dykes (especially set L1) show a "biotite-schist"-like texture characterised by a high biotite content and a densely spaced schistosity. In many cases these L1-dykes acted as pre-formed zones of weakness for ductile shearing and brittle faulting. The mineralogical composition mainly includes biotite and quartz with small amounts of plagioclase and muscovite. Dykes which are only little deformed (i.e. foliation textures), typically belong to 


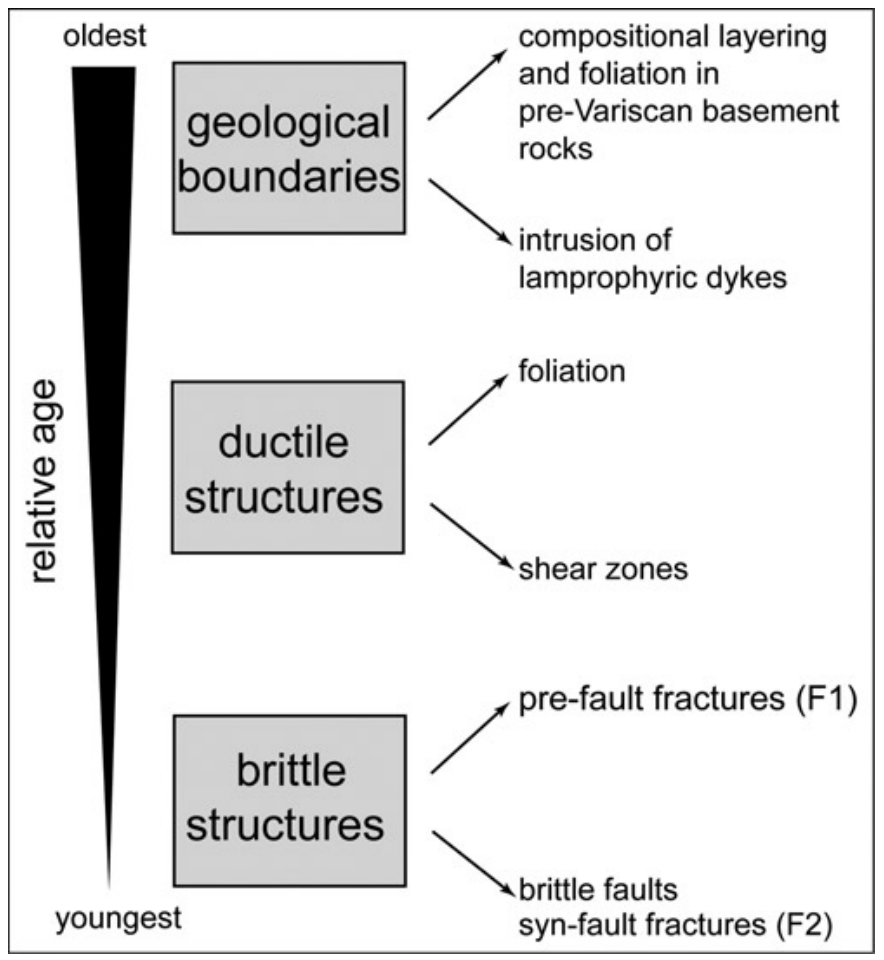

Fig. 7. Scheme of the relative age of anisotropic structures.

set L2 and are composed of amphiboles, feldspar, muscovite, epidote/clinozoisite, chlorite, titanite and biotite. These dykes were not activated as ductile shear or brittle fault zones.

Lamprophyric dykes re-activated as brittle faults zones typically show a sharp boundary (mirror-like fault plane with slickensides) to the intact host-rock (Fig. 8). Adjacent to this fault plane, a layer of fine-grained, greenish, sandy-clayey fault gouge is formed. Fault gouge layers range in thickness from a few $\mathrm{mm}$ to $30 \mathrm{~cm}$ (Fig. 9a). Faulting processes can also incorporate adjacent granitic-gneisses, observed as zones of brecciation. It was rarely observed that these fault zones involved a central gouge layer bounded by damage or fracture zones (Fig. 9a). Some faulted lamprophyre dykes show tight asymmetrical Z-shaped drag folds with a vertically dipping fold-axis, an indicator for right-handed shear (Fig. 8). Microscopic observations of samples of a lamprophyre dyke taken from brittle fault zones also provide evidence for brittle deformation. Micro-fractures, having dimensions of several $100 \mu \mathrm{m}$ and aligned as en-echelon fractures, are filled with low-temperature zeolites, most likely stilbite, characterised by a radial growth texture (Fig. 9b, c). The occurrence of zeolites in fault related fractures and fault zones agrees well with observations in other rock samples deformed by cataclasis, as well as those by Luetzenkirchen (2002) in the Rotondo granite west of the study area.

Due to the lower weathering resistance of paragneisses and schist's of the pre-Variscan basement the outcrop situation for studying the structural architecture of brittle fault zones was less favourable in these lithologies than in the granitic rocks. Nevertheless, observations on a few outcrops showed that the orientation of brittle fault zones in the pre-Variscan basement rock (i.e. para-gneisses and migmatitc gneisses) often is driven through their compositional layering. Compositional layering is created through alternating layers of $\mathrm{cm}$ to $\mathrm{m}$ wide intervals of mica-feldspar gneisses, quartzites, mica-rich schists and amphibolites. Less competent mica rich layers (i.e. schists) of these meta-sedimentary series are predominately sheared, showing abrupt contacts between faulted rock (gouge and fault breccia) and undeformed host rock. Within most of these fault zones, the pre-existing compositional layering is reflected by spatial distributions of fault breccia and gouge that form along layers of low strength.

\subsection{Ductile deformation structures}

Foliation in the granitic gneisses within the study area (e.g. Gamsboden, Fibbia) is defined by aligned mica (muscovite and biotite) grains and shear zone bands (mylonites). Feldspar, quartz grains and mafic xenoliths within the foliation planes are flattened parallel to the foliation strike direction. When ductile shear zones are present the structure of the foliation is characterised by shear zones surrounding lenses of more weakly deformed material (Gapais et al. 1987; Marquer 1990). These zones generally form anastomosing arrays, enclosing lens-shaped domains that underwent smaller and more homogeneous strain. Thus, the overall shear zone pattern consists of mylonitic zones surrounding lenses of lower strain. Nondeformed or weakly foliated domains were rarely observed in the study area, except within the younger Variscan intrusives of Winterhorn, Mt. Prosa and Rotondo granites. The preVariscan basement is characterized by compositional layering and a pre-Alpine foliation formed by preferred orientations of mica grains, and grain boundaries of quartz and feldspar. In general, this foliation is aligned sub-parallel to the Alpine foliation and the pre-Variscan compositional layering except from locations where intensive folding occurred. Alternating layers of schists and gneisses, quartzites, migmatites or amphibolites, and the generally higher mica content, might contribute to an increased anisotropy ratio as compared to the granitic gneisses.

Figure 10 shows the regional distribution of the main foliation in the granitic gneisses and pre-Variscan basement rocks. Local variations in the number of foliation sets and strike azimuth of the foliation do occur, but in general a systematic pattern indicating a mean strike of NE-SW can be seen. Foliation in the northern part of the mapping region dip to the SE, but experience a change in dip to the NW towards the south. Exactly the same structural pattern was found in the highway tunnel at depths of up to $1500 \mathrm{~m}$ below surface. Therefore the main foliation forms the same fan structure as previously described for the brittle fault zones (see Figs. 3 and 10).

Figure 11 provides a photo and schematic representation of a typical fault zone in the Gamsboden-granitic-gneiss that is aligned sub-parallel to the main foliation and a ductile shear 


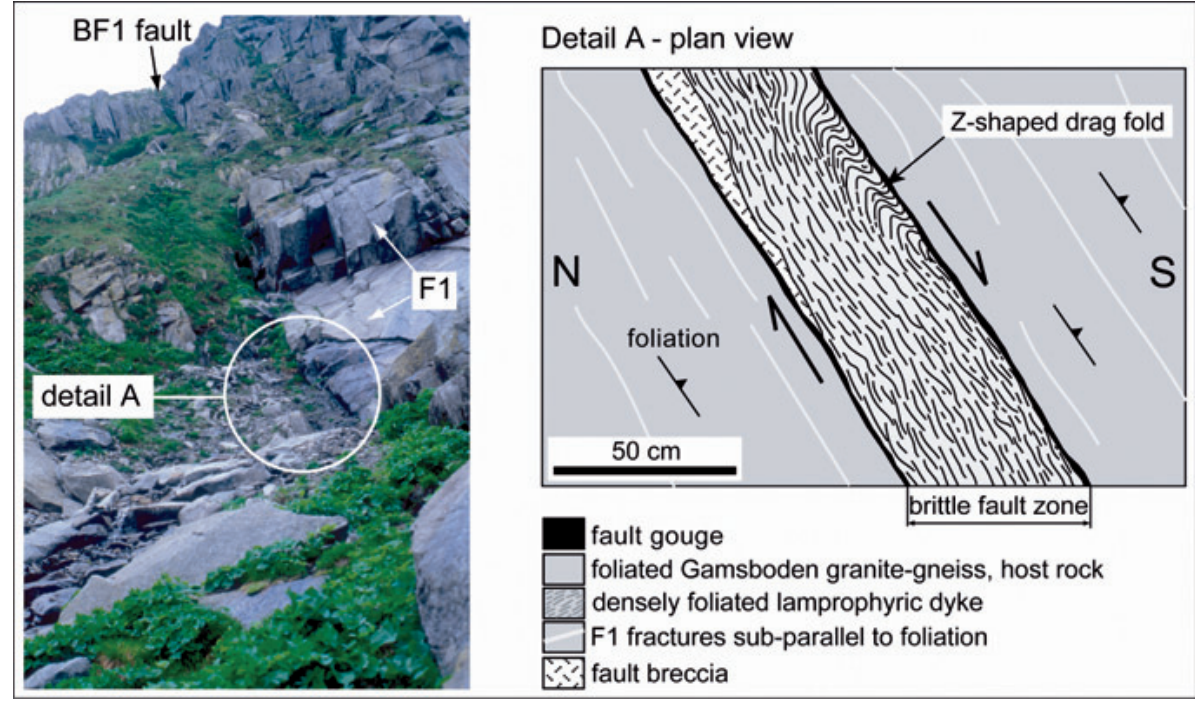

Fig. 8. Photo and plan view of a brittle fault zone initiated on a pre-existing lamprophyric dyke. a.)

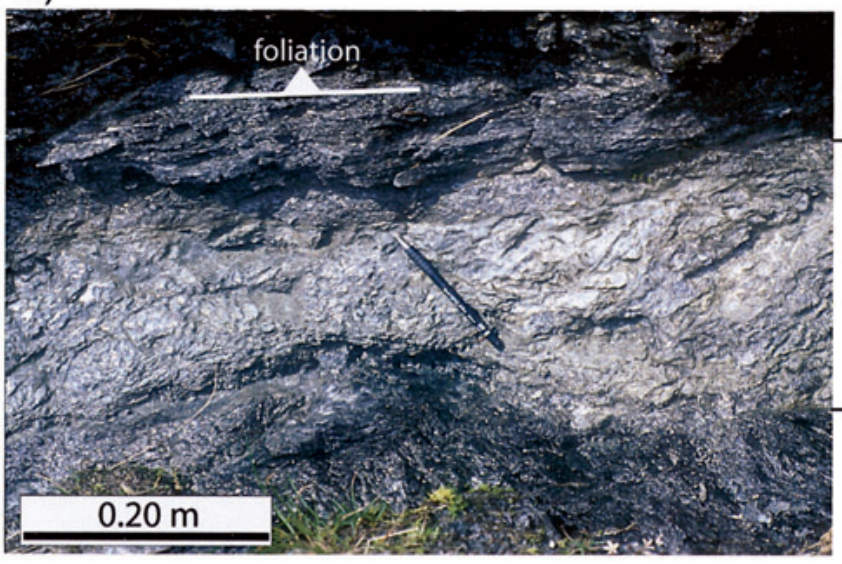

b.)

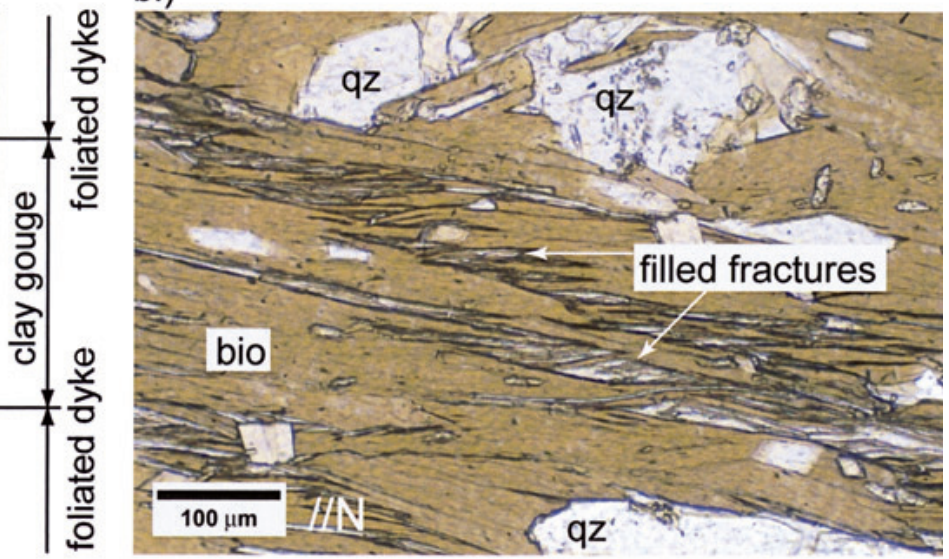

c.)

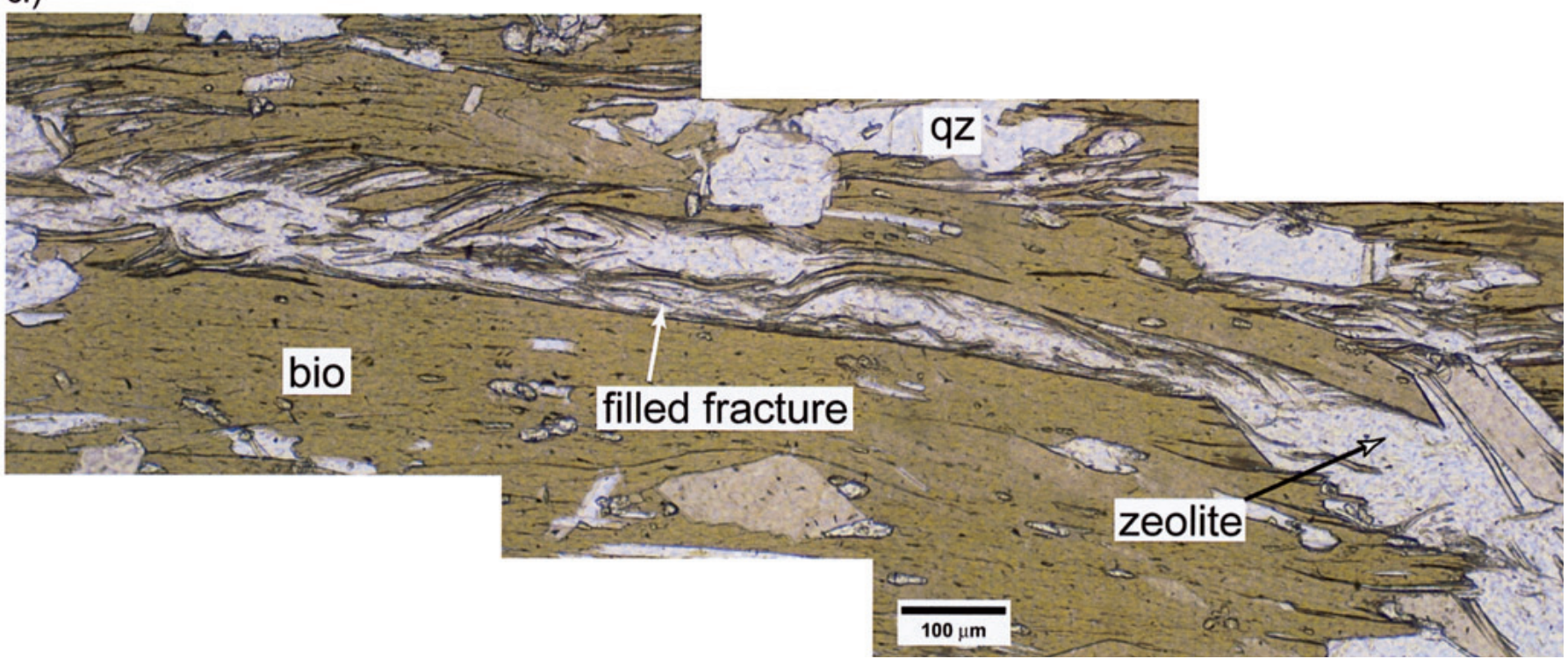

Fig. 9. a) Photo of clayey-sandy fault gouge within a sheared heavily foliated lamprophyric dyke. b) Microscopic view of a foliated lamprophyric dyke, showing enechelon micro-fractures filled with zeolites. c) Large micro-fracture within lamprohyric dykes, aligned parallel to foliation and suggesting tensile opening. 


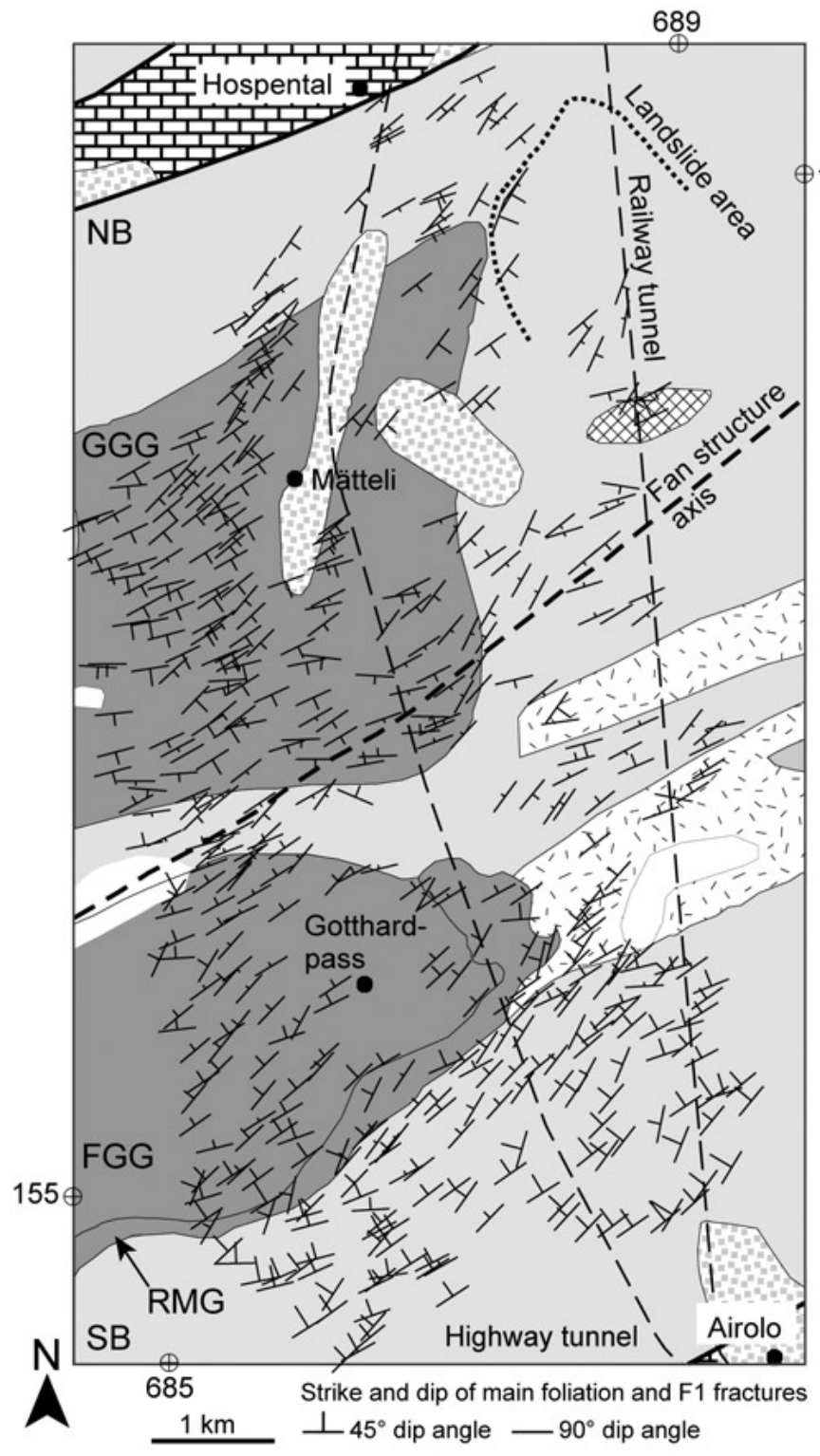

Fig. 10. Structural map of the main foliation as mapped at individual outcrops. See Fig. 2 for legend. Length of dip indicator scaled to dip angle.

zone. Brittle faulting occurred on pre-existing ductile shear zones that are characterised by alternating layers of elongated quartz-feldspar and mica rich bands. Again, these faults are characterised by a sharp contact with the undisturbed host rock where the boundary is often marked by a mirror like fault plane. Adjacent to the fault plane, a several $\mathrm{mm}$ to $\mathrm{cm}$ thick, grey-greenish coloured, clayey to sandy layer of fault gouge can be found. At the contact fault surface, and also within the gouge, striations are present. Adjacent to the gouge zone, mylonitic rock overprinted by fracturing and local brecciation occur. Lenses composed of quartz and feldspar grains are aligned parallel to the shear zone and brecciated. As such, the clayey-sandy fault gouge forms anastomosing arrays around the lenses of pre-existing, partly fractured shear zones (Fig. $11 \mathrm{~b}, \mathrm{c})$. Within the gouge layers, which obtain thicknesses of several $\mathrm{mm}$ to $\mathrm{cm}$, gently plunging slickensides were found. Occasionally shear zone fragments are ductily folded internally and truncated by fault gouge layers, which forms discordant structures between the foliated shear zone fragments and the foliated host rock. Inside the brittle fault zone, foliation- and fault parallel fractures can be seen with increasing frequency as shown in figure 11a. Regarding the fault zone shown in figure 11 its width decreases from $1.5 \mathrm{~m}$ to $0.5 \mathrm{~m}$ over a distance of less then $15 \mathrm{~m}$ sub-vertically. In general, fault zones are smaller than one meter in width but in some cases reach widths of up to $3 \mathrm{~m}$. Similarly, fault gouge layers change in width and frequency along the fault zone.

Figure 12a shows a complete thin section from a fault zone which incorporates cemented breccia and gouge and is orientated perpendicular to the foliation. Three different types of cataclastic foliation structures can be observed: a) layering of fine grained fault gouge and fault breccia, b) foliation within the fault gouge layers characterised by varying colours, grain sizes and seams of secondary and opaque minerals, and occasionally c) foliation within gouge or breccia, defined by subparallel alignment of small grains of muscovite, biotite and chlorite, inclined $0-30^{\circ}$ to the fault boundary (Fig. 12b). The cataclastic foliation of type (a) observed within the brittle fault zone is aligned parallel to the main foliation of the host rock.

Breccias are characterized by densely fractured fragments, encompassed by zones of gouge. Kinked and folded grains of biotite, muscovite and chlorite deform within shear fractures and interpreted as pre-fault mineral grains. A later stage of crystallisation of sericites and zeolites within open voids and open fractures can be observed. Clearly identifiable shear fractures (Riedels) offset these mica layers (foliation type "c" described above) and are partly filled with zeolites (Fig. 12b). More specifically, Ca-Zeolites (stilbite) were identified as the fracture infill by applying optical microscopy, scanning electron microscopy (SEM) with EDS and X-ray diffraction (XRD) techniques. Gouge layers are composed of angular fragments of alkali-feldspar, plagioclase, quartz, clinozoisite/ epidote, zircon and fishes of muscovite, biotite and chlorite (Fig. 12b-d) embedded in a fine grained matrix $(<10 \mu \mathrm{m})$ of quartz, alkali-feldspar, plagioclase, sericite, zeolites (stilbite) and clay-minerals (illite/montmorillonite).

In addition, angular fragments of pre-existing cohesive cataclasites were observed (Fig. 12d), which is found to be in agreement with observations in the Rotondo granite from Luetzenkirchen (2002). Wyder \& Mullis (1998) also found two deformation stages (V and VI) in the Tavetsch massif, where cataclasis was observed as the dominant deformation process. These cataclasite fragments are composed of angular fragments of quartz, plagioclase, alkali-feldspar and mica embedded in a very fine-grained matrix. Fault gouge layers were displaced by Riedel shears (e.g. for the sample shown in Fig. 12a,b, a dextral sense was observed), enclosing an angle between the main cataclastic foliation and the Riedels of 20 to $40^{\circ}$. 


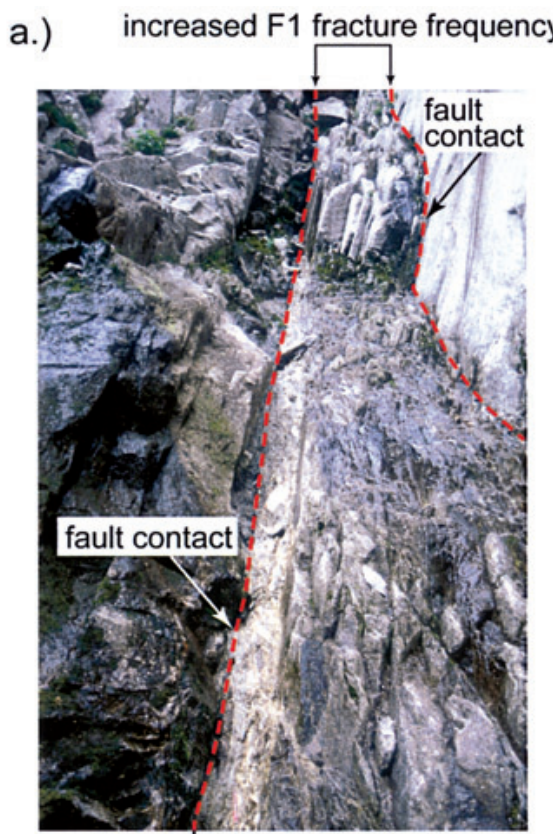

brittle fault zone b.)

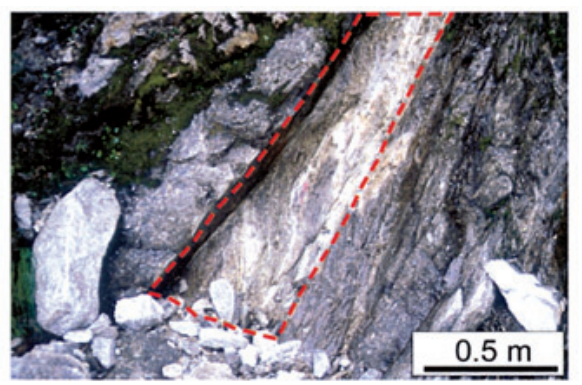

c.)

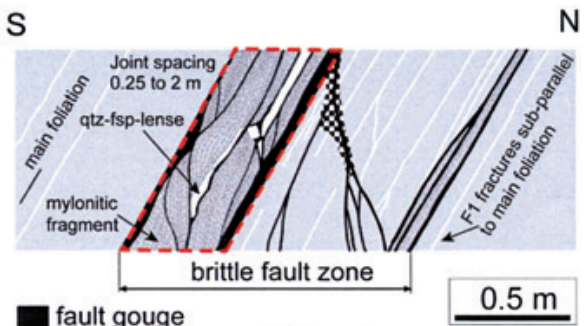

fault gouge

brecciated quartz-feldspar lenses

$\otimes$ brecciated granite-gneiss

foliated Gamsboden granite-gneiss, host rock strongly foliated rock, mylonites

fractures a.)

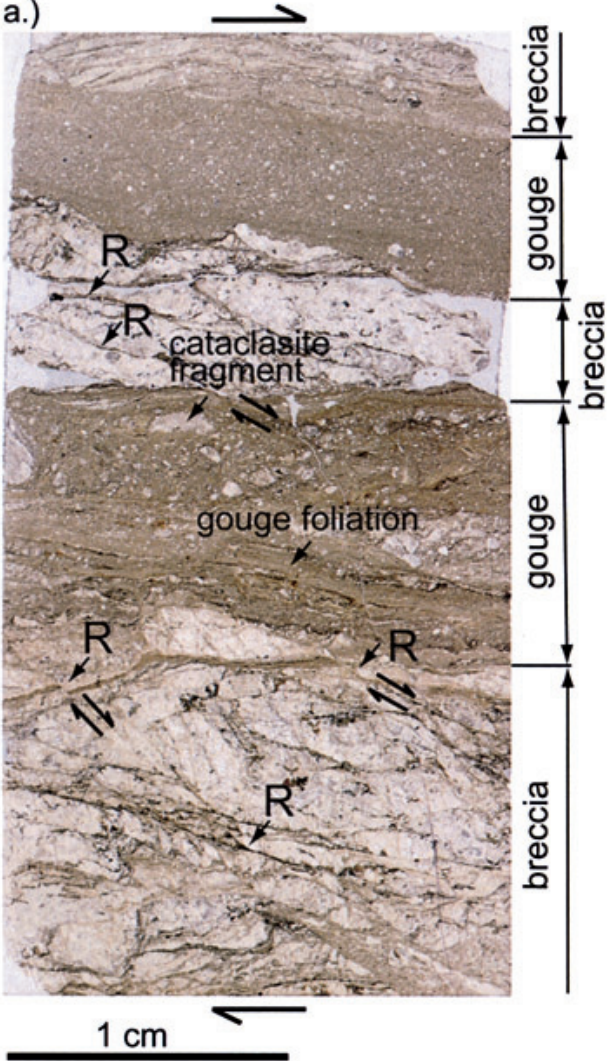

b.)

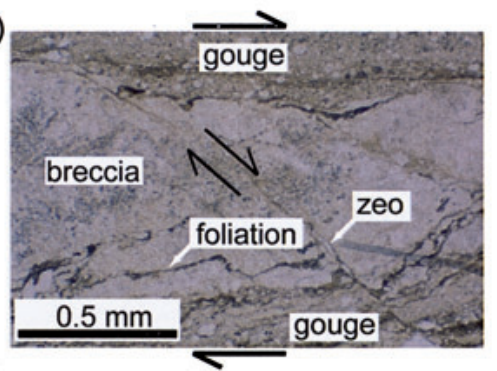

c.)

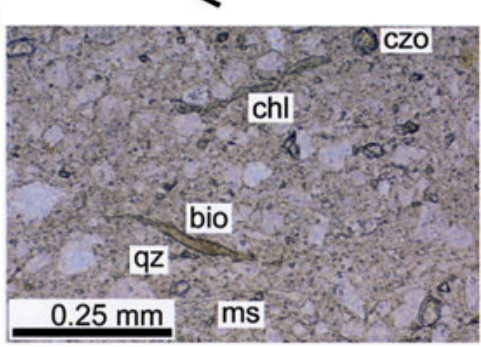

d.)

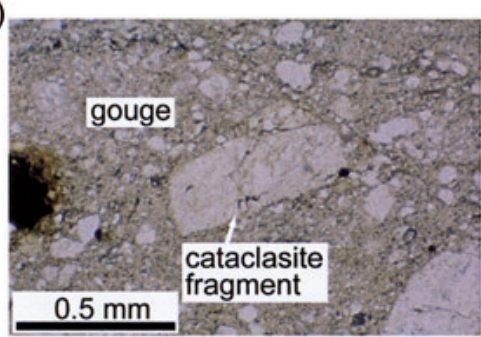

Fig. 11. Photo and front view of a brittle fault zone initiated on a pre-existing ductile shear zone observed in the Gamsboden granitic gneiss: a) Upper part. b) Lower part. c) Front view of the lower part.
Fig. 12. a) Full view of a complete thinsection that shows layers of breccia and gouge oriented parallel to foliation, as observed within the host rock (Gamsboden granitic gneiss). A right-lateral sense of shear could be observed, based on Riedel shears and offset markers. b) Layer of gouge displaced by Riedel shears and indicating a dextral shear sense. Offset of the foliation within the breccia, filled with zeolite (zeo), can be observed. c) Angular fragments of alkali-feldspar, plagioclase, quartz (qtz), clinozoisite/epidote (czo), zircon and fishes of muscovite (ms), biotite (bio) and chlorite (chl) embedded in the gouge matrix. d) Cohesive cataclasite fragment embedded in matrix of fine-grained fault gouge. 


\section{Joint patterns}

\subsection{Joint orientation and morphology}

Up to five meso-scale joint sets were mapped and characterized according to orientation, frequency, spacing and termination properties (Tab. 1 and Fig. 13). The orientation analysis was performed on outcrop (Tab. 1) and scanline data, and was based on contouring the pole density distributions and on cluster analyses as described by Pecher (1989). Concentration parameters, i.e. the measure of the degree of preferred orientation, and the spherical aperture were calculated after Wallbrecher (1986) assuming a 95\% confidence interval (Tab. 1).

The most dominant steeply dipping and NE-SW striking joint set $(\mathrm{F} 1)$ can be found in all rock types belonging to the massif and is orientated sub-parallel to the main foliation and fault structures (Fig. 13). Definition of joint set F1 is based on statistical clustering of orientation measurements, as well as its relationship to the main foliation (Fig. 13). Similar to the previously discussed main foliation and brittle faults, the F1 joints also form a fan structure characterised by an identical NE-SW striking axis. The joint set F1 was mapped as having a mean strike of $49^{\circ}$ in the northern sector of the Gamsboden granitic gneiss, but further south was observed to rotate by $14^{\circ}$ to a mean strike of $63^{\circ}$ (Fig. 13a-c). Scanline data analysis (shown in Fig. 13j, k) produce a trend that is characterised by a mean strike of $40^{\circ}$ along profile I and a mean strike of $52^{\circ}$ along profile II (rotation of $12^{\circ}$ from north to south). Orientation data within the Gamsboden granitic gneiss measured in the safety tunnel show the same F1 cluster striking NE-SW and dipping steeply to SE (Fig. 131).

Within the Fibbia granitic gneiss, located further south, fracture set $\mathrm{F} 1$ strikes $55^{\circ}$ (mean) and $56^{\circ}$ when mapped at outcrops or along scanlines, respectively, and dips steeply to the NW (Fig. 13d, i). The surface morphology, spacing and trace length characteristics of these fractures are similar to those of Gamsboden-granitic-gneiss. Adjacent to the Fibbia granitic gneiss, F1 fractures were measured within the thin layer of Rotondo- and Mt. Prosa-granite, which underwent only minor ductile overprinting during Alpine deformation and macroscopically often shows a granitic texture. These F1 fractures strike $26^{\circ}$ along measured scanlines and $20^{\circ}$ at individual outcrops (Fig. 13g, h). As such, F1 fractures were seen to rotate with respect to the same F1 set within the Fibbia granitic gneiss and the southern basement rocks by approximately $30^{\circ}$.

Surface mapped F1 fractures within the southern preVariscan basement rocks (i.e. amphibolites, para-gneisses and migmatites layers) show a mean strike of $58^{\circ}$ and $48^{\circ}$, and dip only 50 to $60^{\circ} \mathrm{NW}$. Data collected from the tunnel indicate steeper dips $\left(60\right.$ to $\left.75^{\circ}\right)$ but with little variation in the mean strike (i.e. 48 and $57^{\circ}$ ).

On a more localized scale, the strike of the fractures varies following the foliation or the anastomosing pattern of the shear zones. This variation in strike ranges from 0 to $20^{\circ}$ from the mean. Within basement rocks, the strike of the F1 fractures is continuous and parallel to that of the foliation. Within
Table 1. Statistical orientation analysis based on outcrop joint measurements

\begin{tabular}{|c|c|c|c|c|}
\hline Rock unit & Joint set \# & $\begin{array}{l}\text { Mean orien- } \\
\text { tation dip } \\
\text { direction / } \\
\text { dip angle }\left(^{\circ}\right)\end{array}$ & $\begin{array}{l}\text { Number of } \\
\text { disconti- } \\
\text { nuities }\end{array}$ & $\begin{array}{l}\mathrm{R} \%^{1} / \\
\text { Sph. Ap }\end{array}$ \\
\hline $\begin{array}{l}\text { Gamsboden granitic } \\
\text { gneiss (GGG) }\end{array}$ & $\begin{array}{l}\text { F1 and F2 } \\
\text { F3 } \\
\text { F4 } \\
\text { F5 }\end{array}$ & $\begin{array}{l}151 / 69 \\
239 / 80 \\
002 / 50 \\
270 / 27\end{array}$ & $\begin{array}{l}276 \\
195 \\
170 \\
112\end{array}$ & $\begin{array}{l}86 / 21.8 \\
87 / 21.4 \\
84 / 23.5 \\
84 / 23.9\end{array}$ \\
\hline $\begin{array}{l}\text { Fibbia granitic gneiss } \\
\text { (FGG) }\end{array}$ & $\begin{array}{l}\mathrm{F} 1 \text { and } \mathrm{F} 2 \\
\mathrm{~F} 3 \\
\mathrm{~F} 4\end{array}$ & $\begin{array}{l}325 / 72 \\
235 / 86 \\
163 / 30\end{array}$ & $\begin{array}{l}206 \\
168 \\
149\end{array}$ & $\begin{array}{l}83 / 24.0 \\
82 / 25.0 \\
83 / 24.7\end{array}$ \\
\hline $\begin{array}{l}\text { Rotondo, Mt. Prosa } \\
\text { granite (RMG) }\end{array}$ & $\begin{array}{l}\mathrm{F} 1 \\
\mathrm{~F} 2 \\
\mathrm{~F} 3 \\
\mathrm{~F} 4\end{array}$ & $\begin{array}{l}288 / 77 \\
345 / 60 \\
047 / 77 \\
179 / 42\end{array}$ & $\begin{array}{l}40 \\
28 \\
28 \\
36\end{array}$ & $\begin{array}{l}90 / 18.8 \\
88 / 20.2 \\
89 / 19.7 \\
85 / 22.5\end{array}$ \\
\hline $\begin{array}{l}\text { Southern basement } \\
\text { (SB) }\end{array}$ & $\begin{array}{l}\text { F1 } \\
\text { F3 } \\
\text { F4 }\end{array}$ & $\begin{array}{l}322 / 56 \\
064 / 90 \\
168 / 50\end{array}$ & $\begin{array}{l}145 \\
180 \\
159\end{array}$ & $\begin{array}{l}87 / 21.0 \\
77 / 29.0 \\
87 / 21.2\end{array}$ \\
\hline
\end{tabular}

${ }^{1}$...Concentration parameter after Wallbrecher (1986), Measure of the degree of preferred orientation, $\mathrm{R} \%=0$ uniform distribution and $\mathrm{R} \%=100$ parallel planes.

${ }^{2}$...Spherical aperture - Radius of a small circle of a spherical normal distribution. Analysis based on a $95 \%$ confidence interval.

granitic rock bodies the same general trend was observed but in exceptional cases a variation in strike between foliation and F1 fractures of up to $30^{\circ}$ was measured (Fig. 14b). The length of $\mathrm{F} 1$ fracture traces is general within the range of centimetres to several metres and their surfaces are generally planar to curviplanar with very rough and undulating faces. Occasionally, flat plunging striations on F1 surfaces (totally or partly) indicate shear deformation. Whereas some fractures of set F1 are filled with biotite, muscovite, quartz, feldspar, calcite and Fe-hydroxides, others from the same set are totally unfilled.

A second joint set (F2) strikes almost E-W (mean strike $80^{\circ}$ ) and dips steeply to the north and/or south (Figs. 13 and 14). The mean of the F2 set cluster is not well defined, and partially overlaps with F1 or F3 clusters. As such, the distinction between the F1/F3 and F2 clusters becomes impossible if it is done visually on a stereographic contour plot or by statistical clustering methods. But when assigning joints to sets in the field at individual outcrops, the distinction becomes easier, as can be shown on sub-horizontally orientated trace maps (Fig 14). In general, F2 fractures propagate from the tip of F1 fractures (an exception is shown in Fig. 14b) and extend from only one side of F1 fractures. The angle between the strike of F1 and F2 joints is within a range of 20 to $50^{\circ}$. Through observations of termination, angle and propagation relationships, F2 joints were interpreted as secondary fractures and therefore syn-tectonic to shearing of F1 joints. Mostly, F2 joints propa- 


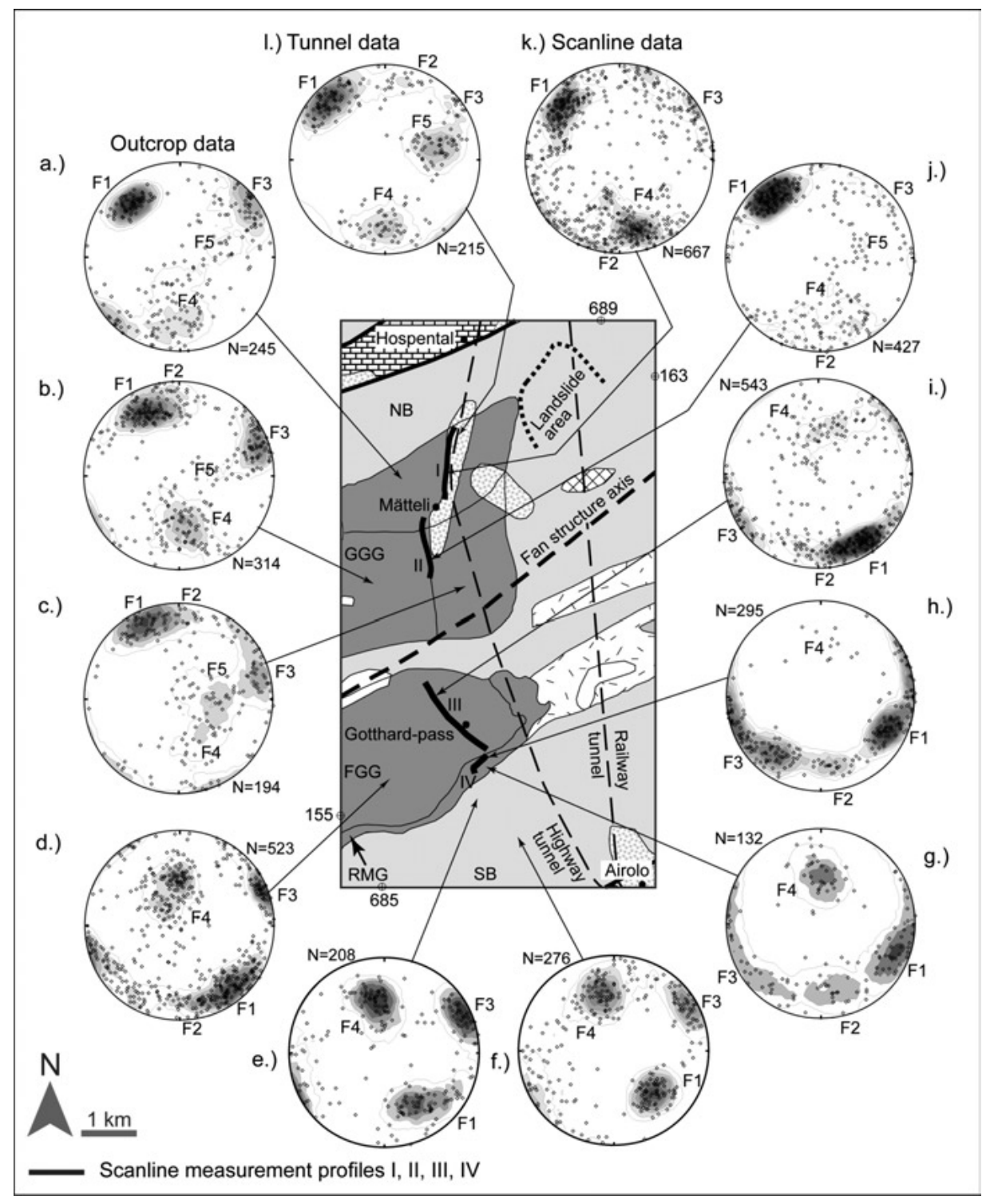

Fig. 13. Location and orientation of joints that are sampled on surface and within the Gotthard highway safety tunnel (l) through outcrop (a-g) and scanline (h-k) measurements. See Fig. 2 for legend.

gate in such a way that a right-lateral shear for F1 fractures can be deduced. F2 fractures were also measured in the Gamsboden-granitic-gneiss at depth, along unlined sections of the Gotthard highway tunnel (Fig. 131). F2 joints were not observed in the pre-Variscan basement rocks.

In contrast, the third joint set (F3) observed in all rock types strikes NW-SE and often is characterised by hydrothermal alteration processes forming alteration seams and greenish-coloured infill coatings of chlorite and occasionally epidote (Fig. 13). The surfaces of these fracture faces are much more planar and smooth than the others, and trace lengths of up to several decametres were observed. The large dispersion of pole points seen in stereonet plots is related to conjugate shear, hybrid and additional opening mode fractures (e.g. Hancock 1985) recognised in the field by mutual abutting/cutting relationships within the set. These conjugate and hybrid shear joints show one of two different orientations: a) the intersection line between the conjugate joint planes dips subvertically and the acute bisector (dihedral angle $2 \theta$ ) is aligned around a NW-SE striking axis, or b) the intersection line between the joint planes strikes NW-SE and the acute bisector is aligned around a sub-vertical axis.

Typically, information regarding joint surface morphology and other surface features are rarely available because outcrops and rock faces generally only allow for two-dimensional joint traces. Several exposures within the Gamsboden granitic gneiss, however did enable the observation of fully exposed joint faces for set F3 which showed plumose structures. On the boundary of these joint surfaces, especially of those with a persistency on the scale of several metres, fringes of en echelon fractures of a few centimetres length, orientated with an acute angle relative to the joint and filled with chlorite in a horizon- 


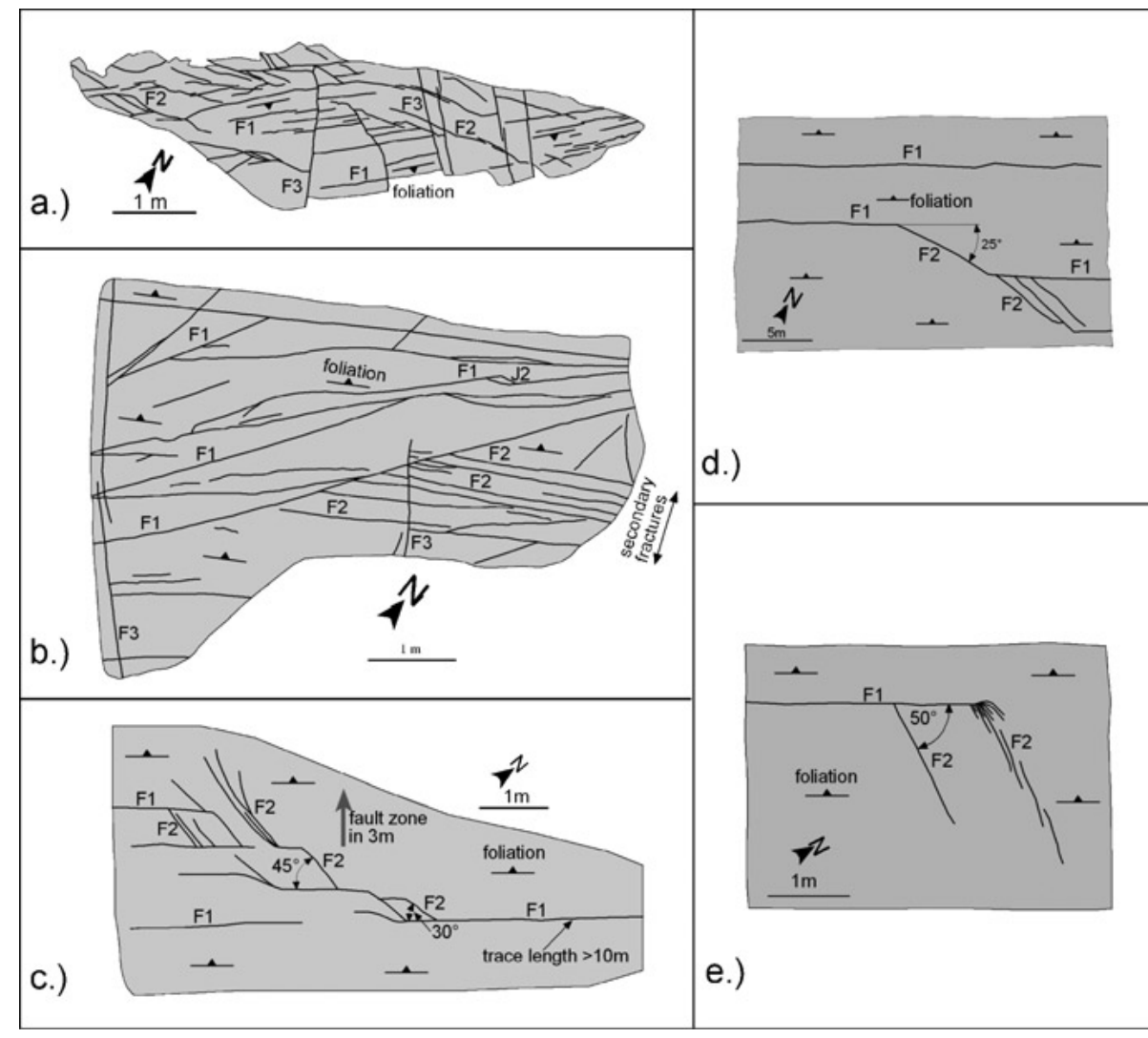

Fig. 14. Outcrop trace maps of meso-scale joints, mapped within the Gamsboden- and Fibbia granitic gneiss showing secondary fractures (F1, F2, F3...joint sets). tal direction, were observed. Based on Pollard \& Aydin (1988), these joint surfaces can be interpreted as having formed by Mode I opening, with the small fringe of en echelon fractures possibly forming in Mode III. Other F3 joints were seen to terminate on foliation planes or the older F1 joints. According to the characteristics of the plumes, fracture initiation and propagation occurred vertically.

The medium to flat dipping joint set F4 and F5 (Fig. 13) are interpreted as unloading joints, since they follow the smoothed topography of the Gotthard massif mountain ridge. Such unloading joints form near surface during uplift, glacial relaxation and erosion. As such, in the northern pre-Variscan basement rocks and Gamsboden-granitic-gneisses, these joints dip either west (F5) or north (F4). In contrast, F4 joints measured within the southern pre-Variscan basement rocks, the Rotondo- and Mt. Prosa-granites, and the Fibbia-granitic-gneisses, predominately dip to the south. In between, i.e. within the northern part of the Fibbia-granitic-gneiss and the preVariscan basement rocks, the F4 joints tend to dip sub-horizontally. Clearly recognizable plumose structures were found on faces of F4 joints of medium grained lamprophyric dykes, suggesting that their formation occurred under Mode I conditions (Bahat et al. 2005; Einstein \& Dershowitz 1990). The trace lengths of the F4 and F5 fractures reach several 10's of metres and they terminate on F1 and F3 joints. Lateral extension of these younger joints was likely arrested at their inter- section with pre-existing/older joint planes, assuming that the effective normal stresses acting across the F1 or F3 joints was sufficiently low (Ruf et al. 1998). F4/F5 joints occur either as a discrete single joint or as a "joint zone" of closely spaced subparallel joints (Engelder 1987).

\subsection{Joint spacing and frequency}

The normal-set spacing obtained along a line that is parallel to the mean normal to set was calculated for each joint set within the Gamsboden-granitic-gneiss. Figure 15a shows the normalset spacing distribution of F1 joints defined by a mean spacing of $0.47 \pm 0.06 \mathrm{~m}$, as measured on surface along scanline profiles I and II (Fig. 13). An upper and lower limit of the spacing population mean was calculated for a $95 \%$ confidence interval based on Priest (1981). The reciprocal value to the mean normal spacing of $2.1 \mathrm{~m}^{-1}$ represents the linear joint frequency assuming a negative exponential probability distribution fit to the data. The mean spacing calculated at depth, along a segment of the Gotthard safety tunnel 550 to $1250 \mathrm{~m}$ below surface, reaches $1.68 \pm 0.58 \mathrm{~m}-$ a joint density which is 3.6 times lower than that measured on the surface (Fig. 15b). The mean normal-set spacing for joint sets F3, F4, and F5 are $1.31 \pm 0.39$ $\mathrm{m}, 0.91 \pm 0.21$ and $0.90 \pm 0.35 \mathrm{~m}$, respectively. Thus, a linear fracture frequency between 0.8 and $1.1 \mathrm{~m}^{-1}$ was found. It should be noted that the construction of a plot for the spacing 

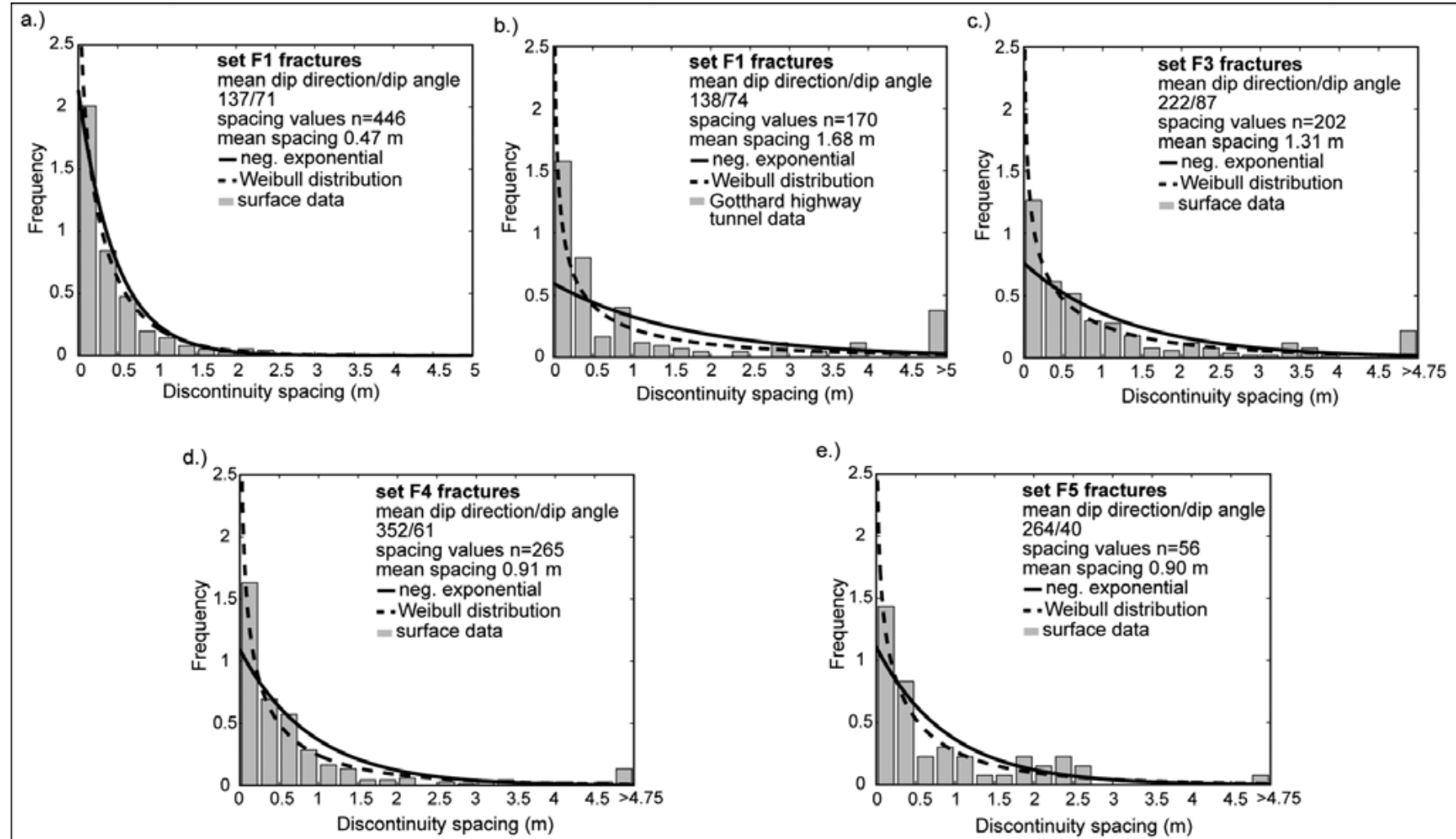

Fig. 15. Normal set spacing distributions obtained from scanline data (see Fig. 13) within the Gamsboden granitic gneiss for: a) F1 joints measured on surface. b) F1 joints measured in the Gotthard highway safety tunnel. c) F3 joint set measured on surface. d) F4 joints set measured on surface. e) F5 joint set measured on surface.

histogram of F2 joints was not possible, given the difficulty in separating them from F1, F4 and especially F3 joint sets, statistically.

On the basis of the "maximum likelihood" algorithm (assuming a $95 \%$ confidence interval), parameters for the negative exponential- and Weibull-distributions were estimated from the spacing data. The negative exponential distribution is fully defined by one single parameter, the mean of the sample, whereas the Weibull-distribution requires two parameters, a scale- and shape parameter (Bardsley et al. 1990). If the shape parameter is equal to one, then the Weibull-distribution matches that of the negative exponential distribution.

Visually, the two distributions show a good fit to the normal-set spacing histogram for F1 joints measured at surface (Fig. 15a). But when comparing the "empirical cumulative distribution function" obtained from the data set with the negative exponential and Weibull cumulative distribution functions plotted based on the maximum likelihood parameters, the Weibull distribution shows a clearly better fit. A shape parameter of 0.85 was determined for the Weibull distribution. Even more distinct differences were found between both probability distribution types for the F1 joint set sampled within the
Gotthard safety tunnel. There, only the Weibull-distribution adequately fits the spacing data (Fig. 15b). The Weibull-distribution was also found to provide a better fit for the fracture spacing distributions of sets F3, F4, and F5, as derived from the scanline data (i.e. profiles I and II; see Fig. 13) for the Gamsboden-granitic gneiss (Fig. 15c-e).

Field observations for the examples shown in figures 8 and 11, where the scanline spacing data was measured across brittle fault zones in granitic gneisses, suggest no increase in meso-scale fracture frequency towards the fault zone. Figure $16 \mathrm{a}$ shows the fracture frequency measurements for another example involving a scanline mapped across a $0.5 \mathrm{~m}$ wide fault zone in the Fibbia granitic-gneiss. A semi-variogram based on joint spacing weighed against joint sequence number (Villaescusa \& Brown 1990) shows a pure "nugget" effect with a "sill" too high to represent randomly positioned joint intersection points (i.e. a 1-D Poisson process, Fig. 16b). In other words, the plot suggests a general "clustering" of joints randomly located across the fault zone and not concentrated to areas adjacent to the fault (as would be expected if the faulting process had influenced the fracture density near the fault zone). 


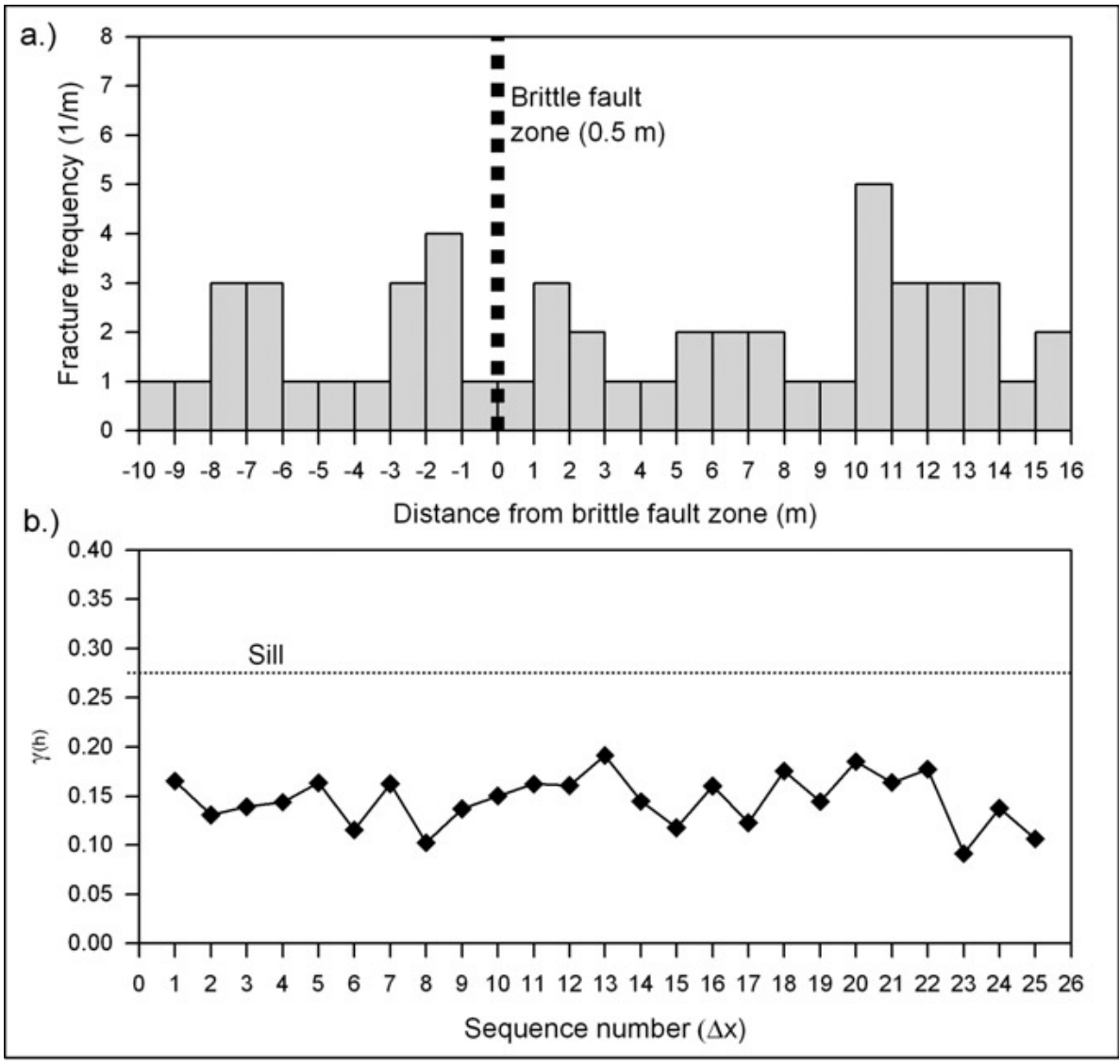

Fig. 16. Brittle fault zone within the Fibbia granitic gneiss: a) Fracture frequency near a $0.5 \mathrm{~m}$ wide brittle fault zone. b) Semi-variogram based on discontinuity spacing by sequence from scanline data.

\section{Discussion}

\subsection{Formation of Brittle Fault Zones}

Shear deformation on pre-existing joints, especially near fracture tips, leads to development of secondary fractures (synfault fractures). These secondary fractures are usually small joints (i.e. theoretically Mode I fractures) that tend to propagate oblique to the associated pre-existing slipped joint, enclosing an angle of 20 to $50^{\circ}$ (less frequently up to $70^{\circ}$ ) and extending from only one side of the fault (Granier 1985; Martel 1997). Anisotropy formed through meso-scale joints can activate faulting processes when shear tractions acting along their surfaces induce fracture parallel slip (Martel et al. 1988; Martel 1990). Subsequent deformation then acts to produce a gouge or other structures related to mechanical wear, as is common with typical faults.

Faulting of F1 joints would in turn create syn-fault secondary joints (F2), propagating oblique to the associated preexisting sheared fracture enclosing an angle of 20 to $50^{\circ}$. Laboratory experiments and numerical models predict that the orientation of secondary fractures emanating from fault tips will vary according to: a) the ratio of shear stress to effective normal stress responsible for kinking (Cruikshank et al. 1991), b) in response to variations in fault-parallel normal stress
(Willemse \& Pollard 1998), and c) as a function of frictional strength along the fault (Cooke 1997). The strike of the secondary fractures is consistent with the shear sense observed on the fault zones.

The following pieces of evidence for suggesting a similar model for the formation of brittle fault zones in the Gotthard massif and in favour of the hypothesis of fault nucleation along pre-existing F1 joints are: a) occurrence of secondary fractures at F1 tips, b) shear sense derived from termination and orientation relationships of secondary fractures corresponding with the shear sense observed on strike-slip faults, c) missing geometric or kinematic relationships between faults and F1 joints, suggesting that they were not formed under the same stress regime, $d$ ) meso-scale fracture frequency does not increase towards the fault zones, e) traces of slickensides observed on very rough, undulated or stepped F1 joint surfaces (originally evolved as mode I fracture), revealing subsequent shearing episodes, and finally f) parallelism of fractures showing slickensides (mode II fractures) to F1 fractures characterised by rough undulated or stepped surfaces and therefore interpreted as mode I joints. Based on these field observations we suggest a reactivation of pre-existing F1 joints to have formed "faulted joints", and later when strain increased, to have formed brittle faults zones. 
Micro-scale observations on samples of brittle fault zones that are aligned parallel to the overall foliation show alternating layers (mm width) of gouge and breccia (Fig. 12a). The alternating character and abrupt transition from intensely deformed gouge layers to much less deformed breccia layers suggest an influence of pre-existing anisotropy during this faulting process. As shown in thin sections through brittle fault zones (Fig. 12), faulting is a multi-stage process whereby foliation planes visible within cataclastic breccia layers are displaced through right lateral Riedel shears, which themselves are younger than the gouge and breccia layers (Fig. 12b).

Precipitation of biotite, chlorite, muscovite, quartz or feldspar within F1 joints indicate that some of the F1 joints were formed during greenschist facies conditions at temperatures above $300^{\circ} \mathrm{C}$ after the peak of the Alpine metamorphism. Similar mineral parageneses were found by Laws (2001) in the Central Aar massif in infilled fractures around ductile shear zones. Temperatures below $300^{\circ} \mathrm{C}$ can be attributed to the formation of mineral parageneses (low temperature zeolites) observed in mafic fault rocks from brittle faults in the Gotthard massif (Luetzenkirchen 2002) supporting the hypothesis of F1 fracture induced brittle fault zones. A decrease of the F1 joint frequency with depth and the numerous observations of unfilled F1 joints suggest that a later fracturing phase, possibly during early uplift and erosion, generated other fractures with similar orientations.

\subsection{Formation of Fracture Sets}

The shape of the fracture spacing histograms provides insight into the spatial occurrence of discontinuities and their genesis. A pure 1-D Poisson process would have suggested independent spacing values that follow a negative exponential probability density distribution (Chilès \& de Marsily 1993). Numerous authors have reported a negative exponential distribution for the total joint set spacing they've mapped (e.g. Priest 1981; Wallis \& King 1980). However, when separating the orientation data into individual joint sets and plotting the normal-set spacing histograms for each set, Chilès \& de Marsily (1993) found that a negative exponential distribution did not fit. Field observations and geostatistical analysis showed that the spacing distributions cluster during the fracturing process. This was observed by others who reported that Weibull or log-normal probability density distributions provided a remarkably better fit to joint spacing histograms (Rouleau \& Gale 1985; Boadu \& Long 1994). Similar results were found in this study for the central Gotthard massif, where a Weibull-distribution provided the best fit (characterized by shape parameters between 0.69 and 0.85 ). Even for the brittle fault zones mapped, where the total spacing was calculated from three different fault sets, a better fit was achieved using a Weibull-distribution characterized by a shape parameter of 0.81 .

Boadu \& Long (1994) concluded that by nature of the better fit they obtained using fractal and Weibull distributions, that a repetitive fragmentation process was responsible for the formation of their fracture pattern. Rives et al. (1992) performed analogue and numerical experiments and concluded that joint spacing distributions evolve from those that are initially negative exponential to those that are log-normal and normal with increasing joint development. Putting this into context for the central Gotthard massif, the deviation of the joint set spacings from that of a negative exponential distribution suggests that the joints have undergone significant development. It is important to note that joint sets F3, F4 and F5 are not aligned sub-parallel to pre-existing rock mass anisotropy (e.g. foliation planes), where the influence of foliation on the fracturing process is such to promote a more randomly spaced joint pattern. Occasionally, field observations in the Fibbia granitic gneiss showed that the F4 joint set was prone to remarkable clustering, i.e. smaller joint traces were grouped adjacent to a large joint causing short spacings between fractures from the same cluster and longer spacings between the clusters ("joint zones"). Although the mechanical processes that promote the formation of densely spaced multiple fractures are poorly understood, the genesis of the F4 joint can be related to unloading processes and therefore likely formed under predominately tensile effective stress conditions (Mode I). These field observations contradict the theoretical findings of Pollard \& Segall (1987), who used linear elastic fracture mechanics to propose that the maximum tensile stress is strongly reduced perpendicular to the joint plane after fracture generation and therefore new fracturing is prevented within a certain distance. It should be noted though that many studies in the published literature relate to joint formation in sedimentary rock masses, which in turn are characterized by rock layers of variable thickness and joint sets orientated perpendicular to the bedding planes. Given that the nature of anisotropy in crystalline rocks is quite different, direct correlations with findings on fracturing behaviour in sedimentary rocks may not be possible.

\section{Summary and conclusion}

The Gotthard pass area offers excellent insights into the brittle deformations occurring within the low-grade metamorphic Variscan granites and pre-Variscan gneisses, schists, migmatites and amphibolites of the Gotthard massif. Three families of brittle faults zones and 5 sets of joints have been identified. All of these brittle structures are of Alpine age and postdate the main phase of ductile Alpine deformation and temperature dominated regional metamorphism. The three sets of brittle fault zones strike NE-SW, NNE-SSW and WNW-ESE, and they formed through cataclasis at temperatures below $300{ }^{\circ} \mathrm{C}$ (Ca-Zeolite stability). Concurrent observations were made by Luetzenkirchen (2002), who mapped brittle fault zones which strike NE-SW within the central, and ENE-WSW to E-W within the eastern Gotthard massif, respectively. Measured slickensides predominantly gently plunge NE-SW. The thickness of the fault zones varies from $\mathrm{cm}$ to several $\mathrm{dm}$, but can reach a maximum of up to $3 \mathrm{~m}$. The density of brittle faults in the central Gotthard massif is very high 
and exhibits a complex geometric pattern. No significant differences between faults zones occurring in plutonic rocks of Variscan age and the pre-Variscan basement could be observed, and all brittle faults post-date ductile deformation structures.

Field evidence suggests that re-activation of the first tensile joint set F1 in shear led to the formation of secondary fractures (F2), "faulted joints" and brittle fault zones. The third fracture set F3 is also steeply oriented and often characterized by hydrothermal alterations and plumose surfaces. The fourth and fifth fractures sets (F4, F5) are medium to flat dipping and are related to erosion and unloading processes. Spacing distributions obtained from the brittle fault zones and all joint sets showed that fracturing may not follow a randomly distributed mono-phase fracturing process, but is dominated by a "clustering" mechanism. The magnitude of clustering increased for joint sets cutting the main foliation at an obtuse angle.

A regional fan structure was established in the Gotthard Pass area, encompassing the main Alpine foliation, steeply dipping meso-scale joints (F1) and brittle fault zones, each of which show the same orientation and location of the symmetry plane (NE-SW orientated). It is suggested that the creation of this fan structure can be correlated with the back folding south of the external massifs and the formation of the Chiera synform (Löw 1987) and the updoming of the external crystalline massifs (Burkhard 1999). This event occurred either near the Oligocene-Miocene boundary (Schmid et al. 1996) or in the lower Miocene (Grindelwald Phase of Burkhard 1999).

These brittle deformations occur on many different scales at very high frequencies and thus are critical for many practical applications. Among others, it could be shown that these brittle deformations have a strong impact on rock mass permeability, deep groundwater circulation, tunnel inflows and drainage (Luetzenkirchen 2002), and coupled rock mass deformations leading to substantial surface settlements above deep tunnels (Zangerl et al. 2003). The study of these attributes is also of significant importance in the Gotthard pass area due to the major tunnel construction projects underway (AlpTransit Base Tunnels).

\section{Acknowledgements}

The authors would like to thank the maintenance team of the Gotthard A2 highway tunnel for their permission to enter the safety tunnel. Thanks also to Dr. Richard Tessardi from University Innsbruck for the X-ray diffractometry analysis and to Dr. Auke Barnhoorn for his kind support on the scanning electron microscope. In addition, we would like to thank Dr. Susanne Laws and Dr. Volker Luetzenkirchen for numerous discussions during the field mapping campaign and to Dr. Martin Brändli for his great support on the GIS system.

\section{REFERENCES}

Angelier, J. 1994: Fault slip analysis and palaeostress reconstruction. In: Hancock, P.L. (Eds.): Continental deformation, 53-100 Pergamon Press.

Arnold, A. 1970: Die Gesteine der Region Nalps-Curnera im nordöstlichen Gotthardmassiv, ihre Metamorphose und ihre Kalksilikatfels-Einschlüsse. Beiträge zur Geologischen Karte der Schweiz, 138, 128 pp

Bahat, D., Rabinovitch, A., Frid, V. 2005: Tensile Fracturing in Rocks, Tectonofractographic and Electromagnetic Radiation Methods. Springer, Heidelberg, 569 pp.

Bardsley, W.E., Major, T.J. \& SElby, M.J. 1990: Note on a Weibull property for joint spacing analysis. International Journal of Rock Mechanics and Mining Sciences \& Geomechanics Abstracts 27(2), 133-134.

BOADU, F.K. \& LONG, L.T. 1994: Statistical distribution of natural fractures and the possible physical generating mechanism. Pure and Applied Geophysics 142(2), 273-293.

Brosch, F.J., Schachner, K., Blümel, M., Fasching, A. \& Fritz, H. 2000: Preliminary investigation results on fabrics and related physical properties of an anisotropic gneiss. Journal of Structural Geology 22, 1773-1787.

BurkHARD, M. 1999: Strukturgeologie und Tektonik im Bereich Alp Transit. In: Löw, S. \& Wyss, R. (Eds.): Symposium Geologie Alptransit, Zuerich, 45-56, Balkema Rotterdam/Brookfield.

Cartwright, J.A., Trudgill, B.D. \& Mansfield, C.S. 1995: Fault growth by segment linkage: An explanation for scatter in maximum displacement and trace length data from the Canyonlands Grabens of SE Utah. Journal of Structural Geology 17, 1319-1326.

Chilès, J.P., \& G. DE MARsily 1993: Stochastic models of fracture systems and their use in flow and transport modelling. In: Bear, J. et al. (Eds.): Flow and Contaminant Transport in Fractured Rock, 169-236, Academic Press, San Diego, California.

CoOKe, M.L. 1997: Fracture localization along faults with spatially varying friction. Journal of Geophysical Research 102(B10), 22425-22434.

Cruikshank, K.M., ZhaO, G. \& Johnson, A. 1991: Analysis of minor fractures with joints and faulted joints. Journal of Structural Geology 13(8), $865-886$.

Deichmann, N., Baer, M., Braunmiller, J., Ballarin Dolfin, D., Bay, F. Delouis, B., FÄH, D., Giardini, D., Kastrup, U., Kind, F., Kradolfer, U., Künzle, W., Röthlisberger, S., Schler, T., Salichon, J., Sellami, S., SPÜHLER, E. \& Wiemer, F. 2000: Earthquakes in Switzerland and surrounding regions during 1999. Eclogae geol. Helv. 93, 395-406.

DERShOwITZ, W.S. \& EINSTEIN, H.H. 1988: Characterizing rock joint geometry with joint system models. Rock Mechanics and Rock Engineering 21, 21-51.

Einstein, H.H. \& Dershowitz, W.S. 1990: Tensile and shear fracturing in predominately compressive stress fields - a review. Engineering Geology 29, 149-172.

Eckardt, P., Funk, H. \& LabHart, T. 1983: Postglaziale Krustenbewegungen an der Rhein-Rhone-Linie. Vermessung, Photogrammetrie, Kulturtechnik 2, 42-56.

ENGELDER, T. 1987: Joints and shear fractures in rock. In: Atkinson B.K. (Eds.): Fracture mechanics of rock, 27-69, Academic Press Inc., London.

EsAKI, T., Du, S., Mitani, Y., IKUSADA, K. \& Jing, L. 1999: Development of a shear-flow test apparatus and determination of coupled properties for a single rock joint. International Journal of Rock Mechanics and Mining Sciences 36, 641-650.

Frey, M., Bucher, K., Frank, E. \& Mullis, J. 1980: Alpine metamorphism along the geotraverse Basel-Chiasso - a review. Eclogae geol. Helv. 73, 527-546.

Gapais, D., Bale, P., Choukroune, P., Cobbold, P.R., Mahjoub, Y., \& MARQUeR, D. 1987: Bulk kinematics from shear zone patterns: some field examples. Journal of Structural Geology 9, 635-646.

Gaudemer, Y. \& TAPOnNiER, P. 1987: Ductile and brittle deformation in the Northern Snake Range, Nevada. Journal of Structural Geology 9, 159-180.

Gottschalk, R.R., Kronenberg, A.K., Russell, J.E. \& Handin, J. 1990: Mechanical anisotropy of gneiss: Failure criterion and textural sources of directional behaviour. Journal of Geophysical Research 95(B13), 21613-21634. 
Granier, T. 1985: Origin, damping, and pattern of development of faults in granite. Tectonics 4(7), 721-737.

Guerrot, C. \& STEIger, R.H. 1991: Variscan granitoids in the Gotthard-massif, Switzerland: $\mathrm{Pb}-\mathrm{U}$ single zircon and $\mathrm{Sr}-\mathrm{Nd}$ data. Terra abstracts 3, 35.

HANCOCK, P.L. 1985: Brittle microtectonics: principles and practice. Journal of Structural Geology 7(3/4), 437-457.

Herwegh, M. \& Pfiffner, O.A. 1999: Die Gesteine der Piora-Zone (Gotthard-Basistunnel). In: Löw, S. \& Wyss, R. (Eds.): Symposium Geologie Alptransit, Zürich, 77-88, Balkema Rotterdam/Brookfield.

KASTRUP, U. 2002: Seismotectonics and stress field variations in Switzerland. Ph.D. Thesis, ETH Zurich, 153 pp.

Keller, F., Wanner, H. \& Schneider, T.R. 1987: Geologischer Schlussbericht Gotthard-Strassentunnel. Beiträge zur Geologie der Schweiz, Geotechnische Serie, Schweizerische Geotechnische Kommission, Bern, 70, $67 \mathrm{pp}$.

Kvale, A. 1966: Gefügestudien im Gotthardmassiv und den angrenzenden Gebieten. Sonderveröffentlichung der Schweizerischen Geotechnischen Geologischen Kommission, 106.

LABHART, T.P. 1999: Aarmassiv, Gotthardmassiv und Tavetscher Zwischenmassiv: Aufbau und Entstehungsgeschichte. In: Löw, S. \& Wyss, R. (Eds.): Symposium Geologie Alptransit, Zürich, 31-43, Balkema Rotterdam/Brookfield.

LA PoINTE, P.R. 1993: Pattern analysis and simulation of joints for rock engineering. In: Hudson, J.A. (Eds.): Comprehensive Rock Engineering: Principles, Practice and Projects, Vol. 3, 215-239, Elsevier.

LAwS, S. 2001: Structural, geomechanical and petrophysical properties of shear zones in the eastern Aar-massif, Switzerland. Ph.D. Thesis, ETH Zurich, $168 \mathrm{pp}$.

Löw, S. 1987: Die tektono-metamorphe Entwicklung der Nördlichen Adula-Decke (Zentralalpen, Schweiz). Beitr. geol. Karte der Schweiz NF $161,84 \mathrm{pp}$.

LUETZENKIRCHEN, V. 2002: Structural geology and hydrogeology of brittle fault zones in the central and eastern Gotthard massif, Switzerland. Ph.D. Thesis, ETH Zurich, 246 pp.

MARQUER, P.D. 1990: Structures et déformation alpine dans les granites hercyniens du massif du Gotthard (Alpes centrales suisses). Eclogae geol. Helv. 83(1), 77-97.

Martel, S.J. 1990: Formation of compound strike slip fault zones, Mount Abbot quadrangle, California. Journal of Structural Geology 12(7), 869-882.

MARTEL, S.J. 1997: Effects of cohesive zones on small faults and implications for secondary fracturing and fault Geometry. Journal of Structural Geology 19(6), 835-847.

MARTEL, S.J. \& BogeR, W.A. 1998: Geometry and mechanics of secondary fracturing around small three-dimensional faults in granitic rock. Journal of Geophysical Research 103(B9), 21299-21314.

Martel, S.J. \& Peterson, J.E. 1991: Interdisciplinary characterization of fracture systems at the US/BK Site, Grimsel Laboratory, Switzerland. International Journal of Rock Mechanics and Mining Sciences \& Geomechanics Abstracts 28(4), 295-323.

Martel, S.J., Pollard, D.D. \& Segall, P. 1988: Development of simple strike-slip fault zones, Mount Abbot Quadrangle, Sierra Nevada. Geological Society of America Bulletin 100,1451-1465.

Maurer, H.R., Burkhard, M., Deichmann, N. \& Green, A.G. 1997: Active tectonism in the central alps: Contrasting stress regimes north and south of the Rhone Valley. Terra Nova 9, 91-94.

Merz, C. 1989: L'intrusif Medel-Cristallina (massif du Gotthard oriental) Partie I: déformations alpines et relations socle-couverture. Schweiz. Mineral. Petrogr. Mitt. 69, 55-71.

Mollema, P.N. \& Antonellini, M. 1999: Development of strike-slip faults in the Dolomites of the Sell Group, Northern Italy. Journal of Structural Geology 21, 273-292.

OBERHAENSLI, R. 1985: Geochemistry of meta-lamprophyres from the central Swiss Alps. Schweiz. Mineral. Petrogr. Mitt. 66, 315-342.

Oberli, F., Sommerauer, J. \& Steiger, R.H. 1981: U-(Th)-Pb systematics and mineralogy of single crystals and concentrates from the Cacciola granite, central Gotthard massif, Switzerland. Schweiz. Mineral. Petrogr. Mitt. $61,323-348$.
PEACOCK, D.C.P. 1991: Displacement and segment linkage in strike-slip fault zones. Journal of Structural Geology 13, 1025-1035.

PEACOCK, D.C.P. 2001: The temporal relationship between joints and faults. Journal of Structural Geology 23, 329-341.

Peacock, D.C.P. \& Sanderson, D.J. 1991: Displacements, segment linkage and relay ramps in normal fault zones. Journal of Structural Geology 13, 721-733.

PECHER, A. 1989: "SCHMIDTMAC" a program to display and analyze directional data. Computers \& Geosciences 8, 1315-1326.

Persaud, M. \& Pfiffner, O.A. 2004: Active deformation in the eastern Swiss Alps: post-glacial faults, seismicity and surface uplift. Tectonophysics 385 , $59-84$.

Petit, J.-P. \& BARQuins, M. 1988: Can natural faults propagate under mode II conditions? Tectonics 7(6), 1243-1256.

PettKe, T. \& Klaper, E.M. 1992: Zur Petrographie und Deformationsgeschichte des südöstlichen Gotthardmassivs. Schweiz. Mineral. Petrogr. Mitt. 72, 197-211.

Pollard, D.D. \& Segall, P. 1987: Theoretical displacements and stresses near fractures in rock: with applications to faults, joints, veins, dikes and solution surfaces. In: Atkinson, B.K. (Eds.): Fracture mechanics of rock, 277-349, Academic Press Inc., London.

Pollard, D.D. \& AYdin, A. 1988: Progress in understanding jointing over the past century. Geological Society of America Bulletin 100,1181-1204.

PRIEST, S.D. 1993: Discontinuity Analysis for Rock Engineering. Chapman \& Hall, London, $473 \mathrm{pp}$.

PRIEST, S.D. \& HUdSON, J.A. 1981: Estimation of discontinuity spacing and trace length using scanline surveys. International Journal of Rock Mechanics and Mining Sciences \& Geomechanics Abstracts 18, 183-197.

Ramsay, J.G. \& Huber, M. 1987: The Techniques of Modern Structural Geology, Volume 2: Folds \& Fractures. Academic Press, London and New York, $391 \mathrm{pp}$.

Rives, T., Razack, M., Petit, J.P. \& Rawnsley, K.D. 1992: Joint spacing: analogue and numerical simulations. Journal of Structural Geology 14(8/9), 925-937.

Rouleau, A. \& GALE, J.E. 1985: Statistical characterization of the fracture system in the Stripa Granite, Sweden. International Journal of Rock Mechanics and Mining Sciences \& Geomechanics Abstracts 22 (6), 353-367.

Ruf, J.C., Rust, K.A. \& Engelder, T. 1998: Investigating the effect of mechanical discontinuities on joint spacing. Tectonophysics 295, 245-257.

Sausse, J., Jacquot, E., Fritz, B., Leroy, J. \& Lespinasse, M. 2001: Evolution of crack permeability during fluid-rock interaction. Example of the Brézouard granite (Vosges, France). Tectonophysics 336, 199-214.

Schmid, S.M., Pfiffner, O.A., Froitzheim, N., Schönborn, G. \& Kissling, E. 1996: Geophysical-geological transect and tectonic evolution of the Swiss-Italian Alps. Tectonics 15(5), 1036-1064.

SCHNEIDER, T.R. 1979: Gotthard Strassentunnel - Geologischer Schlussbericht Nordseite II Geologie. 305am II 3a-4. Unpublished report, available at the Kantonsbibliothek Uri, 6460 Altdorf UR, Schweiz.

ScHOLZ, C.H. 1968: Experimental study of the fracturing process in brittle rock. Journal of Geophysical Research 73, 1447-1454.

Segall, P. \& Pollard, D.D. 1983: Nucleation and growth of strike-slip faults in granite. Journal of Geophysical Research 88(B1), 555-568.

Sergeev, S.A. \& STEIger, R.H. 1995: Caledonian and Variscan granitoids of the Gotthard massif: New geochronological and geochemical results. Schweiz. Mineral. Petrogr. Mitt. 75, 315-316.

SIBSON, R.H. 1977: Fault rocks and fault mechanisms. Geol. Soc. Lond. 133, 191-213.

Simpson, C. 1986: Fabric development in brittle-to-ductile shear zones. Pure and Applied Geophysics 124, 269-288.

STECK, A. 1968: Junge Bruchsysteme in den Zentralalpen. Eclogae geol. Helv. 61(2), 387-393.

Tremblay, A. \& Malo, M. 1991: Significanc of brittle plastic fabrice within the Masawippi Lake fault zone, southern Canadian Appalachians. Journal of Structural Geology 13(9), 1013-1023.

VillaescusA, E. \& BRown, E.T. 1990: Characterizing joint spatial correlation using geostatistical methods. In: Barton, N. \& Stephansson, O. (Eds.): Rock joints, Balkema Rotterdam, 115-122. 
WALlbReCHER, E. 1986: Tektonische und gefügeanalytische Arbeitsweisen. Enke, Stuttgart, $244 \mathrm{pp}$.

WALLIS, P.F. \& KING, M.S. 1980: Discontinuity spacing in a crystalline rock. International Journal of Rock Mechanics and Mining Sciences \& Geomechanics Abstracts 17(1), 63-66.

Wanner, H. 1982: Galeria Stradale del San Gottardo, Rapporto Finale Lotto Sud - Prohilo Geologico attraverso il tunnel di sicurezza del Gottardo. Unpublished report, available at the Kantonsbibliothek Uri, 6460 Altdorf UR, Schweiz.

Wilkins, S.J., Gross, M.R., Wacker, M., Eyal, Y. \& Engelder, J.T. 2001: Faulted joints: Kinematics, displacement-length scaling relations and criteria for their identification. Journal of Structural Geology 23, 315-327.

WILLEMSE, E.J.M. 1997: Segmented normal faults: correspondence between three-dimensional mechanical models and field data. Journal of Geophysical Research 102, 675-692.

Willemse, E.J.M. \& Pollard, D.D. 1998: On the orientation and patterns of wing cracks and solution surfaces at the tips of a sliding flaw or fault. Journal of Geophysical Research 103(B2), 2427-2438.
Willemse, E.J.M., Peacock, D.C.P. \& Aydin, A. 1997: Nucleation and growth of strike-slip faults in limestones from Sommerset. Journal of Structural Geology 19, 1461-1477.

WYDER, R.F. \& MULLIS, J. 1998: Fluid impregnation and development of fault breccias in the Tavetsch besemant rocks (Sedrun, Central Swiss Alps). Tectonophysics 294, 89-107.

WYss, R. 1986: Die Urseren Zone-Lithostratigraphie und Tektonik. Eclogae geol. Helv. 79(3), 731-767.

ZANGerl, C., Eberhardt, E. \& Loew, S. 2003: Ground settlements above tunnels in fractured crystalline rock: numerical analysis of coupled hydromechanical mechanisms. Hydrogeology Journal 11, 162-173.

Manuscript received April 18, 2006

Revision accepted July 4, 2006 